\title{
CACCHEOY MINERÍA MEDIANA EN LAS PROVINCIAS DE Potosí: LÍPEZ Y PORCO (1830-1850)
}

\author{
Tristan Platt ${ }^{1}$
}

A la memoria de Gunnar Mendoza (1914 -1994)

"Si vienen algunos socios de ustedes y estranjeros, no se cuente para nada conmigo. Parece que $U$ no conociera mi jenio! Convinando el sistema de caccheo con el de hacienda o de jornaleros, todo está conseguido: y únicamente son necesarios mil pesos impendibles en el nuevo proyecto".

Domingo Zambrana, Carguaycollo, 8 de diciembre de $1845^{2}$

\section{* Introducción}

Resumen

El artículo examina la pequeña y mediana minería de la plata en dos provincias de Potosí (Bolivia) durante la República temprana, situándola entre las políticas estatales de rescate y amonedación, y el contrabando por la "ruta de las pastas" hacia Salta y la costa chilena. Se identifica el papel de los "fomentadores" bolivianos, que daban créditos y se encargaban del envío de las "oncitas" de plata desde las provincias al Banco de Rescates. Se analiza los mecanismos de acumulación minera (sin recurso a capitales extranjeros), mostrando cómo la relación "al partir" entre los propietarios y sus "socios" indígenas (cacchas) pudo transformarse en una relación "reglamentada" entre patrón y jornalero. Finalmente, se comparan dos empresas de Porco: Siporo y Huanchaca, ambas se unían en su oposición a la injerencia estatal en las relaciones laborales, y sobre todo contra los intentos del Presidente Santa Cruz de introducir un nuevo Código Minero en defensa de los trabajadores.

Palabras claves: pequeña y mediana minería - caccheo - Potosí - Lípez - Porco.

The article examines small and medium silver mining in two provinces of Potosí (Bolivia) during the early Republic, situating it between state buying, minting policies and smuggling via the "silver road" to Salta and the Chilean coast. The role of the Bolivian providers of small loans is identified, who then collected and sent ounces of silver from the local refineries to the Mining Bank. The mechanisms of mining accumulation (without recourse to foreign capitals) are analyzed, showing how the "share-cropping" arrangement between the mine owner and his Indian "associates" (cacchas) could be transformed into a "regular" relationship between boss and day laborer. Finally, I compare two middle-mining businesses, Siporo and Huanchaca, both were united against State interference in labor relations, especially President Santa Cruz's efforts to introduce a new Mining Code in defense of the workers.

Key words: small and medium silver mining - caccheo- Potosí- Lípez- Porco.
Este trabajo trata de la producción de la plata en dos provincias de Potosí durante las primeras décadas de la República boliviana. En aquel momento existía un deseo de forjar una economía nacional independiente, y un cierto orgullo entre mineros, políticos e intelectuales al pensar que era posible prescindir de la "ayuda" extranjera. Al mismo tiempo, nuevos modelos de organización administrativa del Estado se acompañaban por un cambio en los discursos de las fuentes, ambos crecientemente impregnados por el liberalismo ¿Era posible plantearse una República política de ciudadanos sobre una base mayoritaria de indígenas organizados en comunidades "libres" (ayllus) y "cautivas" (haciendas), y una economía minera arruinada por la guerra de la Independencia? Pronto, sin embargo, se inició una primera fase relativamente autónoma de la minería boliviana en cuanto a modos de capitalización, organización del trabajo, y tecnologías de extracción y beneficio, con características propias que merecen ser re-examinadas. ${ }^{3}$

La minería provinciana invita a una nueva mirada, también, por las numerosas fuentes inéditas que nos permiten comparar y contrastar el conjunto de los centros mineros. Los estudios existentes tienden a tomar casos específicos (p.e. Portugalete, en la Provincia de Chichas,

Recibido: julio 2014. Aceptado: octubre 2014.

1 Emeritus Professor in Anthropology and History, University of St. Andrews, Department of Social Anthropology. 71 North Street, St Andrews, Fife, KY16 9AL, Escocia, RU. Email: tp@st-andrews.ac.uk

2 Archivo Nacional de Bolivia (en adelante ANB), Colección Rück, pieza s/n. MSS Minas, Cía. Bolivar, Potosí, Años 1820-1850. 
o Siporo, en la Provincia de Porco), y sobre esa base llenar el "hueco" entre la minería de la Colonia tardía en Charcas (Tandeter 1992), y el último auge de la plata en la segunda mitad del siglo XIX (Mitre 1981). Pero había una gran diversidad de situaciones e iniciativas en la República temprana, y su variedad refleja un debate fundamental a la hora de comprender el problema y la promesa del país durante un período rico en derroteros alternativos (Platt 1996, 1998 y 2000).

Para remediar este vacío es preciso tomar una perspectiva amplia sobre las cuatro provincias del Departamento de Potosí: Lípez, Chichas, Porco y Chayanta; y reconocer, primero, las diferencias entre las condiciones de producción de la Rivera del Cerro Rico, y las de los "minerales de afuera" donde las tecnologías de refinación, entre otros factores, eran bastante diferentes (Platt 199899). De hecho, y como ha señalado Concepción Gavira (2005 y 2013) para la segunda mitad del siglo XVIII, los "minerales de afuera" en su conjunto habían reemplazado al Cerro Rico como fuentes de la mayor parte de la producción surandina; y lo mismo fue el caso durante gran parte del siglo XIX.

En este artículo me limitaré a comparar las formas de trabajo en la pequeña minería, y particularmente el "caccheo" (la minería "al partir") de las Provincias de Lípez y Porco, con dos empresas medianas de la Provincia de Porco: Huanchaca y Siporo - muy diferentes entre sí-, entre 1830 y mediados del siglo XIX. Aunque las actividades mineras eran tan variadas que ninguna situación aislada puede proyectarse sobre las demás, los pequeños trabajos considerados "sin método" a veces constituían el punto de partida para la formación de empresas "reglamentadas", aunque también podían mantenerse dentro de una racionalidad de "reproducción simple" (lo que las fuentes liberales llamaban el "ocio"), sin lanzarse a buscar ganancias reinvertibles ni crecimiento exponencial. ${ }^{4}$

3 El país seguía dependiente de la importación de un insumo esencial para el beneficio de la plata, el azogue, para la amalgamación, que se traía casi enteramente de Almadén, España, hasta la llegada del producto californiano en 1850 .

4 La importancia del caccheo en el siglo XIX, omitido de su estudio por Antonio Mitre (1981), fue recuperada por Gustavo Rodríguez (1989 y 1991).
Por diferentes que sean los tipos de actividad minera, todos deben considerarse en su relación con las políticas mineras del Estado. Entre 1829 y 1839 , cuando gobernaba el Presidente Andrés de Santa Cruz, hubo un conjunto de medidas que reducían los impuestos mineros (Parkerson 1976), y en 1835 se publicó un Código Minero para reemplazar las Ordenanzas coloniales de México. Pero el Código Minero Santa Cruz fue rechazado por los azogueros propietarios de minas e ingenios, dejando a la minería boliviana sujeta por varias décadas a las ordenanzas coloniales. En la opinión de los azogueros, el Estado no debía interferir en las relaciones laborales, que tendrían que regirse exclusivamente por la "libertad" (o sea, el juicio independiente) del empresario. El Código Santa Cruz ofrecía alguna protección a los trabajadores frente a los abusos y la negligencia patronales; y las críticas de los azogueros provocaron la reacción airada del Presidente, que condujo en 1836 a la suspensión del Tribunal General de Minería que él mismo había creado, en 1829 , a petición del propio Gremio de Azogueros. ${ }^{5}$

Además de la discusión sobre las "responsabilidades" del capitalista (nudo contencioso que se agudizaría en el siglo XX y se prolonga hasta el presente), los sistemas productivos analizados aquí corresponden a un período de vigilancia e intervención por parte del Estado boliviano a través de los Ministros de Hacienda, los Ministros de la Casa de Moneda y del Banco de Rescates de Potosí, los Alcaldes Veedores de los Distritos de Minas, los Prefectos departamentales, los Gobernadores de Provincia, y los pequeños Corregidores de Cantón. A cambio del monopolio del rescate de los marcos de plata por los Bancos Mineros de Potosí, Oruro y La Paz, el Estado intentaba facilitar ciertos insumos a precios razonables (sobretodo el azogue, cuyo precio se había disparado en el mercado mundial). Su intervención hizo posible la primera recuperación del rescate potosino, cuyo monto se elevaba desde ca. 65.000 marcos en 1815 hasta

5 La creación en Potosí de un Tribunal General de Minería ya fue propuesta en 1799 por el Gremio de Azogueros al último Intendente colonial de Potosí, Francisco de Paula Sanz (m.1812). En muchos respectos, los azogueros republicanos del Cerro Rico miraban hacia atrás, esperando restaurar las condiciones de producción del último auge del Cerro Rico entre 1790 y 1800 (Tandeter 1992). Contrastar, sin embargo, la empresa republicana de los hermanos Ortiz (Platt 1996 y 1998). 
ca. 250.000 marcos en 1840. Junto con la acuñación de monedas febles de pequeñas denominaciones para facilitar el intercambio en el mercado interno y andino, se trata de una coyuntura en la cual se conjugaban los prerequisitos para un proyecto de nación basado en la protección de la economía contra la dominación extranjera (Mitre 1986; Platt 1986 y 1996).

Este proyecto estatal se fracturó porque algunos mineros, especialmente los de las provincias sureñas de Chichas y Lípez, vieron sus intereses mejor servidos por un grupo de rescatadores, algunos procedentes del noroeste argentino, otros bolivianos, quienes se situaban en los distritos mineros del sur o en la frontera. Pues, si bien legalmente toda la plata rescatada debería fluir hacia el Banco de Rescates para su acuñación posterior en la Casa de Moneda, también hubo canales de escape que permitían que una parte de la producción saliera por la frontera argentina, y de ahí a Salta y el Pacífico por la "ruta de las pastas" a cambio de mercancías ultramarinas. Esta ruta, analizada en profundidad por Viviana Conti (2001, 2003 y 2008), cruzaba la Cordillera hacia la costa del Pacífico; desde ahí la mercancía, tanto monedas acuñadas como pastas de plata, seguía hasta Valparaiso, y de ahí por el Cabo de Hornos hacia el Atlántico norte. La sustracción ilegal de pastas de plata cobró fuerza a partir de 1845, y fue una de las causas principales del fracaso del proyecto nacional proteccionista del Presidente Manuel Isidoro Belzú (1848-1855) (Schelchkov 2007).

Por otra parte, cuando la plata se comercializaba legalmente, mediaban otros rescatadores bolivianos entre los pequeños productores mineros y el Banco de Rescates de Potosí; aquellos disponían de un pequeño capital y estaban prestos a aviar y rescatar la producción, encargándose ellos mismos de su envío y venta al Banco. Ofrecían créditos - insumos y "avíos" - a los pequeños productores, incluso azogue comprado en el Banco, de los ingenios cercanos o de las casas de importación. Los caminos de circulación involucraban a varios individuos, hasta hoy poco conocidos, que articulaban una red de rescate y producción hormiga que definía la cotidianidad laboral minera para muchos campesinos agropastoriles que participaban en la pequeña minería de Lípez y Porco. Veremos las operaciones de estos rescatadores a partir de un informe hasta ahora desconocido, que fue enviado en 1852 al Prefecto departamental por un "Aldeano" del Cantón de San Pablo de Lípez. ${ }^{6}$

\section{* El “estado” de la minería potosina EN 1842}

Para el estudio de las actividades mineras en esta época temprana contamos con una fuente sobre la situación de la minería potosina, que corresponde a principios del gobierno del Presidente José Ballivián (1841-1847). Se trata del "Estado en que se halla la industria mineralójica" de 1842-43. . El 26 de septiembre de 1842 Hilarión Fernández, Ministro de Hacienda de Ballivián, iniciando la labor estadística más detallada que hasta entonces se había intentado en la República, ${ }^{8}$ envió su Supremo Circular $\mathrm{N}_{3}{ }_{3}$ a todas las Prefecturas de la República pidiendo detalles sobre las minas de oro, plata, cobre y estaño que se hallaban en trabajo, además de los ingenios u otras máquinas con las cuales se beneficiaban los metales, y un cuadro aproximado de los avances y los problemas de "este precioso ramo".

El Prefecto de Potosí, Rafael de la Borda, remitió entonces copias del Circular al Alcalde Veedor de Minas de la Ciudad de Potosí, Eduardo Subieta, y a los Gobernadores de todas las Provincias del Departamento. Pidió a cada uno que

"dé cuenta a esta Prefectura de todos los conocimientos precisos, espresando la clase de metales que se esplotan en las diferentes minas de su distrito, la ley que rinden en la actualidad, comparada con la que produjeron en los tres años proxime antecedentes,

6 Archivo Histórico de Potosí, Prefectura Departamental (en adelante AHP PD 722 no 1, 1852, Carlos C. Quiróz al Prefecto de Potosí, "En Pro de Su Cantón”, San Pablo, 1.i.1852.

7 ANB MH Prefectura Potosí Recibidas (en adelante, PPR), t.91 $\mathrm{n}^{\mathrm{O}} 35$.

8 La Oficina Nacional de Estadística fue creada en 1843, bajo la dirección de José María Dalence, autor del Bosquejo Estadístico de Bolivia (1851 [1848]). Pero ya habían esfuerzos estadísticos anteriores, por ejemplo los esfuerzos de Catastro bajo el presidente Sucre en 1825-26, o los cuadros pedidos por el Banco de Rescates a los Directorios mineros bajo el presidente Santa Cruz en 1836. ANB MH Tribunal General de Minería (en adelante, TGM) t. 52 n ${ }^{\circ}$ 10. Cf., por ejemplo, la Tabla 3 abajo, para el Estado que presenta el Ylustre Directorio del Asiento Mineral de Tomave (Potosí, 10.ii.1836). También los cuadros mineros publicados en Platt 1996. 
la especie de beneficio a que se les sujeta, el costo de su laboreo, el valor de jornal, si éste se paga en platas o en géneros, y la escasez o abundancia de los brasos destinados a esta industria, comparada con la población de donde se sacan ..."

Los Gobernadores a su vez pidieron informes a los azogueros individuales, y después re-enviaron sus respuestas al Prefecto, en algunos casos acompañándolas con un informe propio sobre el estado de la minería en su Provincia.

El 10 de junio de 1843 el Prefecto, después de recibir los informes del Alcalde Veedor de Minas del Cerro Rico de Potosí, y de los azogueros y Gobernadores de las cuatro Provincias de Lípez, Chichas, Porco y Chayanta, ${ }^{9}$ pasó todo el expediente a los Ministros del Banco Nacional de Rescates para que, en base a los informes y a otros registros y documentos existentes en sus oficinas, formasen una razón detallada de todas las minas que se encontraban en laboreo, con la información adicional que pedía el gobierno [f.68r]. El 14 de agosto de 1843 los Ministros del Banco, Juan Mariano Ybargüen, Bonifacio de Alba y Eduardo Subieta, con la intervención de Mariano Caballero como nuevo Alcalde Veedor de Minas del Cerro Rico, firmaron su informe final al Prefecto, quien entonces envió todo el expediente al Ministerio en Sucre para la atención de Hilarión Fernández. Este expediente se ha conservado en el archivo del Ministerio, ahora guardado en el Archivo Nacional de Bolivia (Sucre), y contiene los informes manuscritos de los azogueros y funcionarios quienes contestaron la solicitud en las Provincias, y un informe sobre el Cerro Rico de Potosí por el Alcalde Veedor de Minas. El resultado de este largo trámite es un cuerpo documental que, con todas sus fallas (que los Ministros del Banco serían los primeros en señalar), nos ofrece para los años 1842-43 la única perspectiva más o menos sistemática que poseemos sobre el estado de la minería potosina en las primeras décadas republicanas. ${ }^{10}$

\footnotetext{
9 Los informes de Chayanta se refieren, principalmente, a las haciendas de beneficio, sin tocar el mineral de Aullagas, donde se estaba terminando la boya de la Sociedad de la Gallofa.

${ }^{10}$ Otros expedientes, más breves, fueron enviados desde los Departamentos de Oruro y La Paz, que no serán analizados aquí.
}

Ahora bien, es imposible conocer las formas del trabajo minero sin tomar en cuenta el tipo de tecnología emplea$\mathrm{da}$ en cada mina e ingenio, que determinaba el proceso del trabajo. Conviene señalar el predominio en las provincias de Chichas, Porco y Chayanta de un sistema de beneficio "por hervición" en fondos de cobre casi ausente de la Rivera del Cerro Rico (Platt 1998-99). En este método, muy distinto del método "de patio" o "buitrón" con indios repasiris mejor conocido en los estudios del beneficio americano (Bargalló 1969), son de una especial importancia tres tipos de máquina: 1 . los hornos de tuesta o calcinación, donde se quitaba el azufre de los metales negrillos (sulfatos de plata) (una operación también necesaria para su beneficio en buitrón); 2. las paradas de fondos de cobre, donde se hervía la harina mineral molida, con agua, sal y azogue; y de allí que cada empresa también tenía 3. una fundición de cobre, donde se manufacturaban y reparaban los fondos (cuya vida útil pudo ser de sólo dos o tres meses) con cobres procedentes de Corocoro (La Paz), ${ }^{11}$ y comprados a través del Banco de Rescates en Potosí (Platt 1998-99).

El "Estado" de 1842-43 nos ofrece detalles sobre tecnología, trabajo y salarios, con alguna información sobre la producción, los accionistas y los ritmos de inversión para algunas empresas activas en las provincias de Potosí (material complementado aquí con otras fuentes, especialmente escritos notariales y correspondencia prefectural). ${ }^{12}$ Cada operación requería un cierto número de trabajadores para su realización. Observemos que el número de obreros en las paradas de fondos fue mucho menor que los repasiris necesarios para pisar las harinas con azogue y sal en el método tradicional de beneficio en buitrón. ${ }^{13}$

En conjunto, se trata de un sector minero muy diverso que, además, estuvo integrado con los ayllus indígenas,

${ }^{11}$ La producción de Corocoro alcanzó su primer tope republicano en 1850 , con un total de 99.000 quintales españoles de cobre. En el mismo año otros 8000 quintales se producían en Oruro y 6000 en Cobija. Ver Biblioteca Nacional de Bolivia, Moreno 681, pp. 154-155.

${ }^{12}$ Esta documentación se conserva en el Archivo Histórico de la Casa de la Moneda, Potosí.

13 Salvo en los ingenios de los hermanos Ortiz, quienes inventaron su propio sistema de beneficio por "circos" (Platt 1996 y 1998). 
debido a la demanda de dinero tributario de éstos, y de sal, combustible y fuerza de trabajo por parte de los mineros. Como veremos, los Curacas recaudadores negociaban con los empresarios para conseguir dinero, o vales a cobrarse contra las remesas de plata en Potosí, echando a sus tributarios a trabajar en las minas y los ingenios hasta ganar los valores necesarios para pagar el tributo a los Gobernadores y al Tesoro Público.

\section{* El "aldeano" de Lípez: Carlos Quiróz}

Empecemos con la minería boliviana en su expresión más simple, tal como se ve en la Provincia de Lípez a principios de la República (Tabla 1).

En 1829, a pesar de los recuerdos lejanos de la Rivera de San Antonio de Lípez y la opulenta "Mesa de Plata" del

\begin{tabular}{|c|c|c|c|}
\hline CENTRO MINERO & Minero & Producción trimestral & Mina propia o ajena \\
\hline \multirow[t]{10}{*}{ PUCASALLI } & Juan Villca & 5 marcos & Con mina \\
\hline & Ylario Choquevillca & o marco 4 onzas & \\
\hline & Casimiro Quispe & 2 marcos & \\
\hline & Luis Quispe & 3 marcos & Con mina \\
\hline & Manuel Quispe & 1 marco 4 onzas & \\
\hline & Mariano Quispe & 1 marco 4 onzas & \\
\hline & León Quespi & 1 marco 4 onzas & \\
\hline & Atanacio Villca & 3 marcos & Con mina \\
\hline & Tomás Villca & En diligencia & Con mina \\
\hline & Regys Quispe & 1 marco 4 onzas & \\
\hline \multirow[t]{6}{*}{ MORUCO } & Manuel Sotar & 1 marco 4 onzas & \\
\hline & Pablo Delgado & o marco 4 onzas & \\
\hline & Leandro Sotar & 1 marco & \\
\hline & Marcos Coria & 3 marcos & Conmina \\
\hline & Pio Mamani & 3 marcos & Conmina \\
\hline & SUBTOTAL & 28 marcos 4 onzas & \\
\hline \multirow[t]{7}{*}{ SANTA ISABEL } & Crispin Calsinas & \multirow{6}{*}{$\begin{array}{l}\text { Todos éstos } \\
\text { trabajan } \\
\text { en los muladares } \\
\text { solamente, } y \\
\text { extraen } \\
\text { apenas } \\
\text { una oncita } \\
\text { a fines del mes }\end{array}$} & \\
\hline & Feliciano Calcinas & & \\
\hline & Manuel Quespi & & \\
\hline & Pablo Quespi & & \\
\hline & Bartolo Quispe & & \\
\hline & Pedro Espíndola & & \\
\hline & Diego Quispe & 3 marcos & \\
\hline \multirow[t]{8}{*}{ SAN CRISTOBAL } & Salbador Cayo & 1 marco 4 onzas & \\
\hline & Sebastián Cayo & 3 marcos & \\
\hline & Selidonio Yani & 2 marcos & \\
\hline & Lucas Yani & 2 marcos & \\
\hline & Mariano Gutierres & 2 marcos & \\
\hline & Santos Quilamani & 1 marco & \\
\hline & Francisco Ibarra & 1 marco 4 onzas & \\
\hline & SUBTOTAL & 13 marcos & \\
\hline TOTAL & & 41 marcos 4 onzas & \\
\hline
\end{tabular}

Tabla 1. La minería en Lípez (1829).

Fuente: AHP PD 62 no 24, Gobernador Pedro Centeno al Prefecto de Potosí, San Antonio de Lípez, 20.ix.1829. 
siglo XVII, los pocos mineros de Lípez eran indígenas que trabajaban en mínima escala, sea en sus propias minas, sea en las "muladares" o en las minas ajenas (probablemente en calidad de cacchas). En cuanto al sistema de avío y rescate, la situación se aclara por un testigo valioso, el "Aldeano" del Cantón de San Pablo, Carlos Quiróz. Quiróz era un pequeño rescatador de metales quien contó su vida y sus negocios en una "Observación" que envió al Prefecto de Potosí en $1852 .{ }^{14}$ Su narrativa procede de un sector que raras veces se escucha entre los papeles del siglo XIX, y nos invita a considerar las formas del pequeño crédito minero ("avíos" o "habilitación") que coexistían en Lípez y Porco para los trabajos "sin método", donde no existían salarios sino solamente el caccheo, o sea, el trabajo "al partir". Confirma la importancia de los créditos del nor-oeste argentino para los pequeños productores de Lípez, y la imbricación del capital salteño con el sur de Bolivia antes y después de la caida de Santa Cruz en 1839.

Nacido en Salta en 1820, "en las emigraciones por la Yndependencia, mi padre Bolibiano y madre Bolibiana", desde los ocho hasta los quince años Carlos Quiróz viajaba con su mamá entre Salta y Chichas rescatando marcos de plata. Con los inicios de la Guerra de la Confederación Perú-Boliviana en 1836 se alistó, a la edad de quince años, con el ejército "de la Patria" con "plazo de soldado distinguido" bajo la bandera del general Braun: "y el '37 abansamos cincuenta leguas al Territorio Argentino". Después de la derrota de la Confederación PerúBoliviana, Quiróz se desmobilizó en Tupiza y se quedó en La Rinconada hasta 1846 como rescatador y conductor de los tejos de oro "y aún pastas de plata" que su "Sra. Madre" reunía entre los veneristas de Chichas y los pequeños productores de Lípez. En este período, Carlos viajaba y compraba tejos y pastas, mientras que su madre los acumulaba en la frontera y los intercambiaba con los rescatadores de Salta.

Ahora bien, en La Rinconada, Quiróz tuvo la suerte de recibir 7000 pesos como avío de un vecino de Salta, Juan de Dios Gareca, que le permitió rescatar metales y en 1845 devolver el principal, llevando como ganancia un incremento de 3000 pesos. Y la devolución a Gareca parece haberse realizado, no tanto con la venta clandestina

\footnotetext{
${ }^{14}$ AHP PD 722 n ${ }^{\circ}$, Carlos C. Quiróz al Prefecto de Potosí, "En Pro de Su Cantón", San Pablo, 1.i.1852.
}

de metales a rescatadores argentinos, sino con la venta legal de los metales al Banco Nacional de Rescates en Potosí. O sea, Quiróz y sus pequeños productores lipeños funcionaban de intermediarios entre el capital mercantil salteño que proveía los avíos por medio de Quiróz, y el Banco de Rescates que pagaba la moneda potosina que tanto se buscaba en las provincias argentinas. Quiróz se refiere a las guías de los metales que bajo su nombre habían ido a Potosí. Y con su capital de 3000 pesos, nuestro pequeño rescatador estaba contento. En 1846 se retiró al pueblo de San Pablo desde donde envió en 1852 su "Observación" al Prefecto. ${ }^{15}$

En su “Observación”, Quiróz también recordó las remesas de plata que, a fines de la guerra con Argentina, se habían enviado desde Lípez al Banco de Rescates en Potosí por dos aviadores bolivianos. El primero, don Sebastián Estupiñán, murió hacía doce años (1840), pero fue "un Padre de todos los mineros y de toda clase de bibientes". Daba avíos de diferentes montos según el giro del receptor: "100 y 200 pesos 10 y 1, según lo que le pedían para marcos, y a nadie negaba", y todos - no importaba cuán pequeña su producción - recibían créditos y una salida para sus "oncitas" de plata. Después de la muerte de Estupiñán, don Leandro Mendivil también enviaba pastas a Potosí hasta el año de 1845, año en que - según Quiróz - empezaron a valorarse los marcos de plata en Salta. Es decir que, además de la plata acuñada procedente de la Casa de la Moneda y el Banco de Rescates, se intensificaba la demanda argentina y chilena de plata piña para enviar sin acuñar como contrabando a Valparaíso, a cambio de importaciones europeas. El testimonio de Quiróz confirma que el contrabando de pastas de plata empezó a ensancharse desde mediados de los 1840, y en 1852 desaparecían fuera de Bolivia casi todos los marcos de San Pablo: "y los pocos que sacan siempre en este Canton no sé donde hirán”, escribe Quiróz, "porque un solo marco ni onza de oro ba a Potosí; en los cinco años que e parado acá solo e dado dos guías al Banco".

\footnotetext{
15 Su auto-identificación como "Aldeano" nos recuerda el conocido Aldeano de Oruro, autor de una valiosa descripción de la economía y sociedad bolivianas en 1830 (Lema et. al. 1994). Posiblemente, ser "aldeano" era un estatus reconocido entre algunos "intelectuales de provincia”, aunque Quiróz se declara "un Aldeano" de 31 años, y "un infeliz Ciudadano, inútil, escaso de nosiones, solo animado al buen éxito de su Cantón".
} 
Estupiñán y Mendivil no tenían mucho capital, pero lanzaron a la circulación $3-4.000$ pesos. En 1852, sin embargo, se había paralizado la actividad legal de los cacchas en Lípez por falta de aviador "visible", aunque Quiróz insinúa que aún venían argentinos invisibles desde Salta para aviar y comprar la pequeña producción clandestinamente. Según Quiróz, la solución sería la llegada de un nuevo "fomentador boliviano", para cortar el flujo de marcos a Salta y producir hasta mil marcos al año para vender al Banco de Potosí. (Un "fomentador boliviano" funcionaría de sustituto por un Banco regional de Rescates, institución que no se pudo justificar debido al giro reducido de la Provincia.)

Ahora bien, para comprender el pensamiento de Quiróz hay que tomar en cuenta que, en 1852 , su mente estaba encandilada por el modelo del caccheo tal como se había practicado en Carguaycollo (Coroma) de la vecina Provincia de Porco. Quiróz consideraba el caccheo como el antecedente clave para la formación en 1850 de la Sociedad Ancona por José Avelino Aramayo. Antes en Carguaycollo, los aviadores fomentaban el trabajo "al partir" con los cacchas, ellos mismos poniendo la mina y/o las herramientas, y dividiéndose el producto metálico con cada caccha. Así, se ahorraban los salarios de los trabajadores, que se remuneraban con la mitad de los metales explotados; éstos después se vendían o se devolvían al dueño de la mina a cambio de más "avíos". En este sentido, el caccha era casi un socio del fomentador, un estatus diferente de la condición dependiente de un "jornalero". Y los mineros reconocieron la importancia del caccheo como una vía de acumulación primitiva minera, que pudo atraer capitales cuando las vetas favorecían. ${ }^{16}$

Las minas de Carguaycollo estuvieron en boya en 1852 , y todos sabían que, hasta la fundación de la Sociedad en 1850 por José Avelino Aramayo, cuyo establecimiento de beneficio estaba en Sevaruyo, el caccheo predominó en ese centro minero. Sin embargo, ahora tenía "una población constante y numerosa, y en proyecto de dos templos". Según Quiróz, en los 1840 s hubo solamente dos fomen-

${ }^{16}$ El 8 de diciembre de 1845 , Domingo Zambrana, director de nuevos trabajos mineros en Carguaycollo, escribió a su compadre Pedro Nolasco Costas en Potosí que el caccheo era la llave del futuro, un mecanismo de acumulación que lo hacía innecesario recurrir a capitales extranjeros. Ver epígrafe de este artículo, también cit. en Platt 1996. tadores: Mariano Costas, comerciante y minero de Potosí, quien perdió hasta 30.000 pesos; y Juan Saavedra, a quien le iba bien con sólo 3.000 pesos: "a éste le llobían piñas, y le hiba de perla con el caccheo con esta friolera". El capital pequeño, según Quiróz, era el más apropiado para aviar al caccheo, quizás porque un capital grande erosionaría la relación recíproca que buscaban los cacchas, amenazando con convertirles en peones en lugar de socios, e invitándoles a aprovechar de avíos ilimitados sin sentir ninguna obligación hacia el aviador. En este tipo de pequeña minería era necesario crear sentimientos de obligación y lealtad en indígenas llameros, para que volviesen al rescatador año tras año.

Sin embargo, según Quiróz, "los indígenas por ci nunca pueden dar en boya a San Pablo, ni otro mineral". En 1852 habían treinta cacchas (sc. indígenas) en San Pablo que trabajaban con estacas (o a veces con un "fierro flamingo"), y "al año asen calsar al año dos beses". Hacía falta un fomentador con 6.000 pesos para "aser boyar a San Pablo, y a los ceis años creo se berían trabajos formales por estar todos los serros entactos, y panizos muy ricos, y a los dos años saldría uno de la duda, el fomentador abilita a ceis pesos ceis rreales plata y genero a ciete pesos marco, y los biberes y todo es mas barato que en Carguaycollo". Pues, si bien Carguaycollo proporcionó el modelo del desarrollo que Carlos Quiróz proyectó para su provincia, la promesa en Lípez era aún mayor:

"Creo a los tres meses de establecido el fomentador aquí, beo que veinte marcos semanales puede contar como espreso el primer año, el segundo naturalmente sería al doble por razón que hay un millón de ramos, es mil beses mejor que Carbaicollo a su principio."

En la base del sistema estaría el fomentador, dando créditos (avíos) a cambio de la pequeña producción, y enviando las piñas y los piñones al Banco de Rescates en Potosí $-o$, clandestinamente, a través de la frontera a Salta.

\section{* Dos vías de acumulación originaria EN LÍPEZ}

Para los 1850 oss tenemos información sobre la creación de dos empresas mineras en Lípez, una equivalente al esfuerzo de Mariano Costas en Carguaycollo, y la otra en la misma escala que su rival Juan Saavedra. Aunque no sabemos 
nada de su destino posterior, pueden servir como ejemplos de dos tipos de capitalización minera.

En 1852 se planteaba, en la vecina Provincia de Porco, la formación de un trabajo minero en Lípez con un capital de arranque de 20.000 pesos. Cuatro azogueros se reunían en la gran hacienda-ingenio de Siporo: Miguel Gantier del mismo Siporo, José María Suárez de Machacamarca, Pedro Palenque también de Machacamarca, y Pedro Dornaleche, vecino francés de Potosí. Se proponia formar la compañía "Restauradora" de Lípez en base a la adquisición y explotación de la legendaria "Mesa de Plata" de San Antonio de Lípez. Cada socio ponía 5.000 pesos, y la sociedad se dividía en seis acciones, una para Gantier y Palenque, y dos para Suárez y Dornaleche. Las acciones adicionales de Suárez y Dornaleche no serían contribuyentes, es decir, los dividendos se dividirían entre las seis acciones, pero las pérdidas entre las cuatro solamente. El Director era Pedro Dornaleche, ${ }^{17}$ y el Administrador de Cerro, José María Suárez; ambos gozarían de un sueldo de 20 pesos semanales (excluyendo los gastos en animales y forrajes), y las dos acciones adicionales eran en compensación por su obligación de vivir tres años en las tierras inhóspitas de Lípez. ${ }^{18}$

En 1852 el Gobernador de Lípez, Esteban Sandoval, escribió al Prefecto desde San Antonio que "en esta sociedad hay minas cuyas vetas se estienden hasta la dimención de dos brasadas de ancho, y corresponde a 40 marcos el cajón, y las demás vetas, cuyos metales se toman a golpe de ojo, no vajan de 25 marco". Sandoval también envió una lista de los cerros de plata y cobre en San Pablo y San Antonio, ${ }^{19}$ y recomendó que se invitase por la prensa a los

${ }^{17}$ En 1845 y 1847 Pedro Dornaleche fue conductor de los caudales enviados por el Banco de Rescates a Cobija en pago de azogues. Ver AHP PD 501 n² 2, Potosí, 8.ii.1845; AHP PD 571 no 1, Potosí, 31.iii.1847. Otro minero cuya carrera se iniciaba como conductor de caudales fue el mismo José Avelino Aramayo, quien ya en 1830 acompañaba los fondos del Banco através de la planicie de Lípez a Cobija. AHP PD 77 nº 70, 72 y 78, Tadeo Telles al Prefecto de Potosí, San Cristobal, 30.xii.1830.

18 Para las claúsulas de la compañía, ver AHP EN (Escrituras Notariales) 226 (ff.106-108v), 8.x.1852.

19 "Cerros con plata en San Pablo: Lamoro, Jatun Orco, Morados, Bera Cruz, Peñasco, Pucasalli, Santa Rosa, San Julián, Barraguayco, Cuebilla, Santa Isabel, Santa Juana, Pampacoya, Comercoya, San Gerónimo, otro Jatun Orco, Santiago y Cobrecobre. De cobre: Señoritayoc, Jancani, Viscachani, Sivincani y Guaylla orco. De oro: Jatun guasi (cerro), relabe mayo, y en Viscachani "capitalistas" de la República a que invertiesen en las minas de Lípez "bajo los auspicios del padre protector de la especie humana el ilustre Jral. Belzú". Al mismo tiempo se empezaba a reconstruir las ruinas de San Antonio: se abrieron la Plazuela de la Libertad, la Plazuela de Suárez (el descubridor - se trata de José María Suárez, Administrador de la empresa) y la Calle de Belzú ... El 2 de diciembre de 1852, Sandoval anunció que habitaban más de 50 vecinos (familias) en San Antonio, todos venidos desde afuera entre los vivanderos y los que habían traído la Sociedad. "Con muy fundadas razones cree el infrascripto que Lípez está a la vanguardia de los ricos minerales y que recién empieza la aurora de su vida". ${ }^{20}$ Pero después, nuestras fuentes quedan calladas.

Con la "Restauradora", entonces, se planteaba un trabajo en escala mayor, con capitales considerables reunidos fuera de la Provincia, que fue precisamente la estrategia que criticaba el "Aldeano" Quiróz. Pero pocos años más tarde se formaría otra sociedad más pequeña pero más conforme a sus recomendaciones. En febrero de $1856^{21}$ doña Mercedes Baldivia, esposa del entonces Gobernador de la Provincia, Juan Bautista Aramayo, se presentó delante del Ciudadano Ygnacio Lazo de la Vega, Juez de Paz de San Cristóbal, capital de la Provincia. Dio su poder al Ciudadano Antonio Lizárraga para que fuera a San Pablo y celebrara un contrato de "compra o sociedad de una mina de plata" pertenciente a cuatro "indígenas contribuyentes", mineros del "ayllo de Santa Isabel" en el asiento mineral de Santa Isabel.

en benero. Cerros en San Antonio de Lípez con plata: Carbonera, Guayco llacta, Collque pirgua, Pabellón, Capachaca, Mesa de Plata, Trinidad, Ariursa [?], Nuevo Mundo, Atoccueva, Mestizo, Socabón y Morejón ..." AHP PD 700 n 28. Esteban Sandoval al Prefecto de Potosí, San Antonio de Lípez, 1.xi.1852.

${ }^{20}$ AHP PD $700 \mathrm{n}^{\circ} 35$. Esteban Sandoval al Prefecto de Potosí, San Cristobal, 2.xii.1852. Un mes antes, Sandoval escribió al Prefecto: "Sorprende la humana credulidad ver como en esta sociedad hay minas cuyas vetas se extienden hasta la dimensión de dos brasadas de ancho, y corresponde a cuarenta marcos el cajón, y las demás vetas, cuyos metales se toman a golpe de ojo, no bajan de veinticinco marcos, cuyas pellitas [muestras de amalgama] remito a Ud por gusto de los ensayes que hoy se han practicado por el socio Ciudadano José María Suárez de Rama ...". San Cristobal, 1.xi.1852.

${ }^{21}$ AHP PDE (Prefectura Departamental Expedientes) 4069 (1856), Solicitud de doña Mercedes Baldivia formando sociedad para trabajar minas con los indios Apolinar, Santosy Tiburcio Condori. 
El papel jugado por los indios en la identificación y el cateo de nuevas minas fue reconocido desde el siglo XVI, y se prolongaba durante el siglo XIX. Aquí se trataba del tributario Santos Condori con sus tres hijos, quienes, habiéndose conseguido primero una licencia de cateo, ubicaron una veta de plata en el cerro nombrado el "Poderoso". La veta se llamaría "Rosario", y la bocamina la "Cruz": se situaban un poco más abajo de la mina del hijo Apolinar en el mismo cerro; y el primer descubridor fue Apolinar. Los Condoris querían denunciar el despueble de la mina y pedir su registro como de su propiedad. En 1855 presentaron una solicitud al Corregidor del Cantón de San Pablo y, de acuerdo con las Ordenanzas, trajeron un pedazo de metal y pella (amalgama) para apoyar su denuncia, pidiendo las tres estacas que le correspondían a Apolinar como descubridor.

Sin embargo, en marzo de 1856 encontramos a la doña Mercedes, a través de su apoderado Lizárraga, cerrando un contrato con los Condoris para trabajar la mina en companía bajo el título de la "Nueva Esperanza". ${ }^{22}$ El acuerdo era que ella se quedaría con cinco acciones, y los Condoris con otras cinco (Apolinar tenía dos como descubridor). Como dueña de la mitad de las acciones, Mercedes se comprometía a poner el "fomento", o sea, "todo el capital que sea necesario para la explotación de metales i consiguiente beneficio". Aquí, bajo la forma legal de una sociedad, donde los Condoris aún mantienen la propiedad de su mina, tenemos instituida una relación un paso más allá que la relación típica entre un propietario-aviador y sus cacchas. En esta versión, los indios eran los dueños de la mina, en lugar de la fomentadora, pero al mismo tiempo podemos sospechar una relación de caccheo entre los cinco propietarios indígenas y doña Mercedes.

El mismo expediente nos muestra los dos próximos pasos en el proceso. Primero vino la compra de la mina de

\footnotetext{
22 En 1856 el Gobernador Juan Bautista Aramayo anunció otras iniciativas mineras. Licencias se habían otorgado a dos Socaboneros, Máximo Mendivil en el Cerro de Santa Juana, y la Sociedad "Cuatro Amigos" dirigido por Manuel Yáñez en el Cerro Santa Isabel. Aparte de la Sociedad "Buena Esperanza", se refiere también a una Sociedad formada entre el indio Santos Calima y la Sociedad "Cuatro Amigos". Se confirma así el papel de los indios tributarios como socios descubridores en la formación de nuevas sociedades mineras. AHP PD $829 \mathrm{n}^{\circ} 12$, Juan Bautista Aramayo al Prefecto de Potosí, San Cristobal, 2.vi.1856.
}

sus socios por doña Mercedes en 4.000 pesos. Para los Condoris esta suma era suficiente para permitirles seguir con su actividad principal: el cateo y registro de minas para su fomento y explotación en pequeña escala, y su venta posterior a un fomentador criollo. Al mismo tiempo, podrían haber seguido de cacchas en las mismas minas que ahora pertenecían a Sra. Baldibia. Por su parte, doña Mercedes no se contentaba con la propiedad absoluta de la mina, sino procedía directamente, en octubre de 1856 , a vender la sociedad de "Buena Esperanza" al Ciudadano Pedro Bustillo en 8.000 pesos "dinero sonante y contante" pagables a 2.000 pesos cada tres meses, con una ganancia de $100 \%$ para la mujer del Gobernador.

Nuevamente, desconocemos el futuro de la sociedad en manos de Bustillo. Los indios, ¿habrían seguido de cacchas ahora asociados con el nuevo dueño? Se percibe, en todo caso, el mecanismo legal por el cual el cateo y registro de una mina pudo dar lugar, primero, a una sociedad entre los indios y un aviador, y después a la compra de las minas valorizadas por el aviador. Éste, entonces, pudo explotar las minas personalmente, o de otro modo venderlas por un precio más alto a otro minero deseoso de invertir en minas que ya prometían un trabajo "entablado". Este mecanismo de atraer capitales hacia la minería en base al trabajo de los cacchas, al mismo tiempo que se iba "arreglando" la explotación, fue el que Quiróz consideró capaz de poner las minas de San Pablo en boya, como fue el caso en Carguaycollo.

Pero el proceso podría despertar el resentimiento de los indios. En 1859 el corregidor de San Pablo, Juan Bautista Goytia, escribió al Jefe Político ${ }^{23}$ de Potosí que dos curacas ("abastonados"), con sus dos concejeros ("cabecillas"), no querían colaborar con los "empresarios de minas" y les quitaba el "servicio" recomendado por decretos supremos. ${ }^{24}$ Se trata de una ruptura en la relación entre los tributarios y las empresas mineras que había permitido a los azogueros aprovechar la oferta local de trabajadores, a la vez que los tributarios podían conseguir el dinero necesario para el pago de sus tributos. No

\footnotetext{
${ }^{23}$ Bajo la dictadura de José María Linares, los Prefectos departamentales se reemplazaban por Jefes Políticos.

${ }^{24}$ AHP PD $917 \mathrm{n}^{\circ} 5$ y 7. Juan Bautista Goytia al Jefe Político de Potosí, San Pablo de Lípez, 31.iii.1859. Los indios rebeldes eran "Andrés Guaita, un Gomes, un Blas Limachi, un Melo ...".
} 


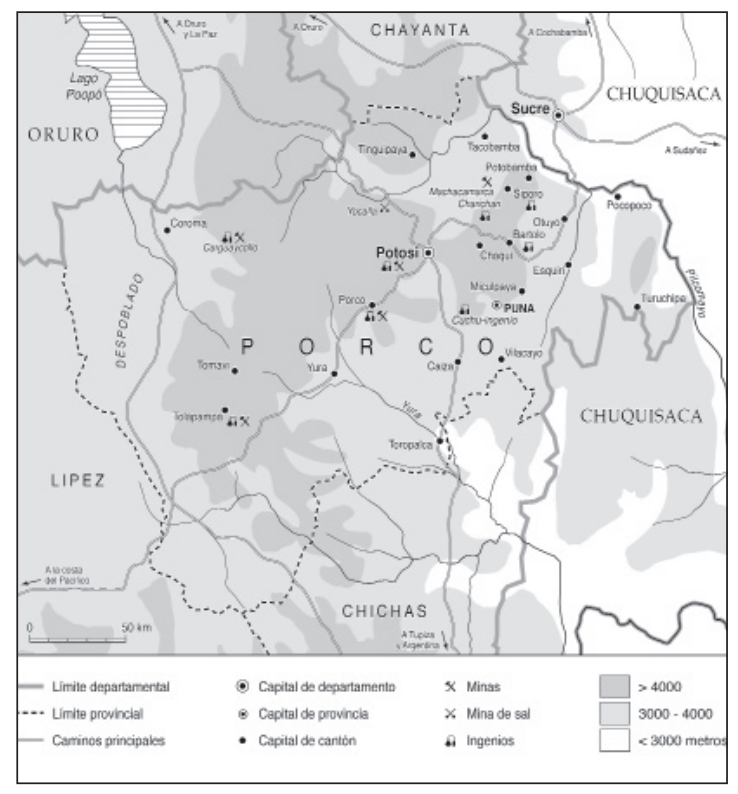

Figura 1. Mapa de la Provincia de Porco en el siglo XIX. sabemos qué tipo de maltrato subyace en la resistencia de los indios, ni la fuente alternativa de dinero tributario que buscaron. Pronto veremos otro ejemplo de "huelga" por los indios tributarios de Siporo, Provincia de Porco, contra los abusos de su patrón minero.

\section{^ Los cacchas de Carguaycollo}

Pasando ahora a la Provincia de Porco, veamos primero la situación en Carguaycollo en 1842, tres años antes de los trabajos en Carguaycollo de Domingo Zambrana y ocho antes de la formación de la Sociedad Ancona de José Avelino Aramayo en 1850. Se trata del punto de partida del proceso que tanto admiró Carlos Quiróz en 1852. La "Razón detallada ... de Tomave y Carguaycollo" (Tabla 2), formada a pedido del Gobernador por el azoguero Clemente Figueroa en 1843, nos muestra una empresa "reciente" en Carguaycollo formada por Ma-

\begin{tabular}{|c|c|c|c|c|c|c|c|c|c|c|c|c|c|c|c|}
\hline 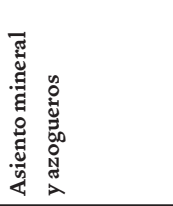 & 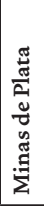 & 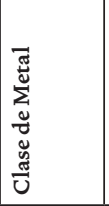 & 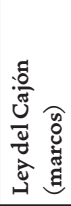 & 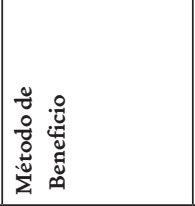 & 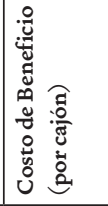 & 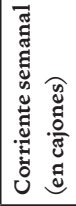 & 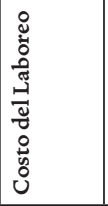 & 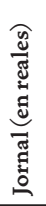 & 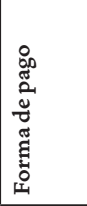 & 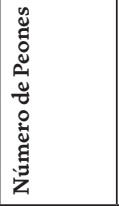 & 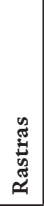 & 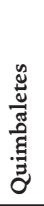 & 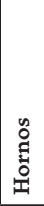 & 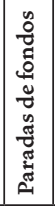 & 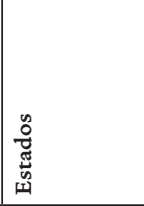 \\
\hline $\begin{array}{l}\text { Tomave } \\
\text { Ignacio G. Ortega } \\
\text { Juan Romero } \\
\text { (Sociedad) } \\
\end{array}$ & 1 & Bronces & 10 & Quema y hervición & 60 pesos & 4 & 80 pesos & $\begin{array}{l}6 \mathrm{r} \\
4 \mathrm{r}\end{array}$ & $\begin{array}{l}\text { Platay } \\
\text { género }\end{array}$ & $\begin{array}{r}55 \\
\text { jornaleros }\end{array}$ & 2 & o & 3 & 4 & Entablado \\
\hline José Figueroa & 1 & Negrillos & 20 & Quema y hervición & 40 pesos & 3 & 50 pesos & $\begin{array}{l}6 \mathrm{r} \\
4 \mathrm{r} \\
\end{array}$ & \begin{tabular}{|l|}
$\begin{array}{l}\text { Platay } \\
\text { género }\end{array}$ \\
\end{tabular} & $\begin{array}{r}40 \\
\text { jornaleros } \\
\end{array}$ & 2 & 1 & 2 & 4 & Entablado \\
\hline $\begin{array}{l}\text { Carguaycollo } \\
\text { Cantón Coroma }\end{array}$ & & & & & & & & & & & & & & & \\
\hline Mariano Costas & 1 & Negrillos & 25 & Quema y hervición & 40 pesos & o & 80 pesos & $\begin{array}{l}8 \mathrm{r} \\
4 \mathrm{r}\end{array}$ & Plata & $23[\mathrm{sic}]$ & 1 & o & 2 & o & Reciente \\
\hline Miguel Zaabedra & 1 & \begin{tabular}{|l|} 
Negrillos \\
\end{tabular} & 75 & Quema y buitrón & o & $\circ$ & $\circ$ & $\circ$ & Metal & 10 cacchas & $\circ$ & 1 & 1 & $\circ$ & Sin método \\
\hline Bonifacio Cayo & 1 & \begin{tabular}{|l|} 
Negrillos \\
\end{tabular} & 100 & Quema y buitrón & o & ○ & $\circ$ & $\circ$ & Metal & 7 cacchas & $\circ$ & 1 & 1 & o & Sin método \\
\hline Rafael Acho & 1 & Pacos & 75 & Crudo y buitrón & o & ○ & $\circ$ & $\circ$ & Metal & 11 cacchas & $\circ$ & 1 & 1 & $\circ$ & Sin método \\
\hline Manuel Pedrozo & 1 & Negrillos & 75 & Quema y hervición & $\circ$ & $\circ$ & $\circ$ & $\circ$ & Metal & 8 cacchas & $\circ$ & 1 & 1 & o & Sin método \\
\hline José Leandro & 1 & \begin{tabular}{|l|} 
Negrillos \\
\end{tabular} & 100 & Quema y hervición & $\circ$ & o & $\circ$ & $\circ$ & Metal & 14 cacchas & $\circ$ & 1 & 1 & 1 & Sin método \\
\hline Pedro Veliz & 1 & Negrillos & 100 & Quema y hervición & $\circ$ & o & ० & $\circ$ & Metal & 20 cacchas & 0 & 1 & 1 & $\circ$ & Sin método \\
\hline TOTAL & 9 & & & & $\begin{array}{l}\text { Gasto } \\
\text { semanal } \\
140 \text { pesos }\end{array}$ & 7 & \begin{tabular}{|r|} 
Gasto \\
semanal \\
210 pesos
\end{tabular} & & & 188 & 5 & 7 & 13 & 9 & \\
\hline
\end{tabular}

Tabla 2. Razón de los asientos mineros de Tomave y Carguaycollo (1842).

Fuente: ANB MH PPR t.94 n 35. Estado en que se halla la industria mineralójica (f.38). "Razón detallada con especialidad y presentada al Gobernador de la Provincia por el asoguero Clemente Figueroa, a mérito de la orden que se le tiene cometida en Circular de 5 de noviembre último, del número de minas que se hallan en actual laboreo en los Asientos Minerales de Tomave y Carguaycollo". Tomave, $30 . x i 1.1842$. 
riano Costas con 23 - "ijornaleros?" "icacchas"? la ambigüedad de la fuente quizás refleje una ambigüedad real -, con metales de 25 marcos por cajón; y otros seis "azogueros" cuyos costos de beneficio, corriente semanal, costo de laboreo y jornal se consignan como cero, al mismo tiempo que las leyes de los metales de sus minas son muy altas: entre 75 y 100 marcos por cajón. ¿Cómo se explica esta paradoja?

En 1842, vemos que todos los mineros de Carguaycollo (menos Mariano Costas, probablemente el mismo "comerciante de Potosí" que - según Quiróz - terminaría perdiendo 30000 pesos en "avíos") trabajaban con 7-20 cacchas cada uno, en lugar de jornaleros. A los cacchas no se les pagaba ningún jornal, aparte de la mitad del metal extraído. Pero para Clemente Figueroa, la ausencia en su informe de "razón ni cálculo aprocsimado que satisfagan a los por menores de este manifiesto" se debía "al trabajo que tienen [los cacchas], sin método, orden ni contracción". Carguaycollo tenía excelentes metales, pero era "el centro de los vicios, donde la inmoralidad y mala fé se hallan en su auje, practicados y fomentados por los propietarios de minas". Con trabajo tan irregular y consentido, ¿cómo podría haber un corriente semanal fijo?

Ahora bien, hemos visto que el caccheo es una relación de trabajo racional y, además, legítima, basada en la noción de reciprocidad (negociable) entre socios. Si se toma como trabajo minero "al partir", la información dada en la Tabla 2 es comprensible. La solución está nuevamente en la forma del pago, que aparece en la Tabla: metal. Los indios cacchas trabajaban para los dueños de las minas a cambio de la mitad del metal extraído, ahorrando a los dueños el costo de jornales. Si los dueños también les aviaban con herramientas de trabajo u otras especies necesarias, el retorno también era en metal.

Además, todos los propietarios de minas en Carguaycollo tenían en 1842 su propio horno donde quemaban las harinas de los negrillos, excepcionalmente ricos, extraídos por los cacchas y molidos con sus respectivos quimbaletes, incluyendo sin duda las harinas que correspondían a los mismos cacchas. Y un propietario de minas, José Leandro, tenía instalada su propia parada de fondos para beneficiar por hervición las harinas quemadas (negrillos) o crudas ( $p a-$ cos). Probablemente arrendaba o "prestaba" sus fondos a Manuel Pedroso y a Pedro Véliz, que no tenían fondos de hervición, y quizás también al único "patrón" del asiento, Mariano Costas. Aunque en 1842 Costas estaba "recién" instalado con 23 trabajadores, y tenía una rastra y hornos para ir acumulando quemadillos, todavía no tenía su propia parada de fondos para beneficiarlos, teniendo que acudir, o a José Leandro, o a uno de los tres propietarios mineros - Miguel Zaavedra, Bonifacio Cayo y Rafael Acho - que seguían con el antecuado método del buitrón (donde sin duda los repasiris eran los mismos cacchas).

El ritmo del trabajo en Carguaycollo en 1842 no respondía a un proceso de acumulación característica de una empresa capitalista: "en todo el año trabajan no más que tres o cuatro meses", escribió Clemente Figueroa, "y el tiempo restante lo emplean en la imbriaguez y el ocio". Podemos entender esta descripción en el sentido de que los cacchas trabajaban sólo para tener plata que gastar. No veían la necesidad de trabajar largas horas durante todo el año para sobrevivir, como en una relación de trabajo asalariada de tipo "moderno", seguramente porque cultivaban sus propias parcelas, o pasteaban sus rebaños, o trabajaban también en otros centros mineros. Las pequeñas minas donde pasaban parte de su tiempo les ayudaban a reproducir estilos de vida a la vez mineros y agropastoriles, no para lanzarse a la acumulación geométrica al estilo capitalista. Todo esto cambió con la formacion de la Sociedad Ancona, en base a la compra en 1850 de las minas de Mariano Costas por José Avelino Aramayo (Mitre 1981), que se inspiró en el ejemplo de las cajas de ahorro de las minas alemanas para poner un fondo social al servicio de los trabajadores en base a deducciones de sus salarios, y exigiendo a cambio una disciplina bien reglamentada. ${ }^{25}$

\section{* El caso de Tomave}

En Tomave, situado más al sur de la Provincia de Porco, cerca de la Sociedad Mineralójica Huanchaca en Tolapampa, el trabajo minero ya estaba "entablado". Hubo unos 95 trabajadores divididos entre dos empresas, una perteneciente a José Figueroa en la hacienda de beneficio de Santa Barbara, y la otra a los dos socios Ignacio González de Ortega y Juan Romero en la hacienda San Baltasar de Charque (Tabla 2). Se trata de un sistema que

\footnotetext{
${ }^{25}$ Ver el Reglamento General de los Trabajos Mineralógicos y Metalúrgicos de la Sociedad Ancona. Potosí: Imprenta Pública de Castillo. 1855.
} 
en 1842 había llegado un paso más allá que Carguaycollo en el proceso de "reglamentación" del trabajo minero.

También tenemos indicaciones sobre el estado de la minería en Tomave seis años antes en 1836 (Tabla 3).

Ya para entonces José Figueroa ${ }^{26}$ tenía dos minas, dos rastras, dos "moliendas en uso" (probablemente trapiches), y dos hornos donde quemaba sus negrillos, que daban 30 marcos por cajón de 50 quintales. Juan Romero, en cambio, tenía una mina "en diligencia" donde acumulaba minerales, y arrendaba otra mina donde molía negrillos con cuatro trapiches, quemando las harinas en dos hornos. Lamentablemente, esta fuente no proporciona información sobre los sistemas de amalgamación, ni sobre el número de los trabajadores en aquel momento. Pero podemos observar cómo las altas leyes del metal en 1836 habían animado a muchos a comprar minas y construir moliendas y hornos de quema en Tomave. Sin embargo, en 1842 todos menos Figueroa y Romero habían desaparecido, y la ley de los minerales había bajado, aunque los trabajos de estas dos empresas se habían ampliado. Según la Tabla 2, Romero ahora trabajaba con Ignacio González de Ortega con 55 jornaleros, mientras que Figueroa tenía contratados a 40. Ambos pagaban los jornales en plata (6 reales) y género (4 reales). Podemos suponer que, en 1842, algunos de los otros mineros de 1836 se habían convertido en los "jornaleros" (o cacchas) de las dos empresas sobrevivientes.

En su hacienda de Santa Bárbara, Figueroa tenía una corriente semanal de tres cajones de metales bronces, con algunos acerados (negrillos), que se extraían de una sola mina en explotación con 27 trabajadores. También se habilitaban otras tres minas con 19 trabajadores. Los minerales se beneficiaban con dos rastras y dos cedazos, que producían tres cajones de harina cernida por semana con ocho trabajadores. Las harinas se pasaban a los dos hornos que quemaban los negrillos día y noche; estaban atendidos por seis

26 José Figueroa parece haber sido un pionero en el Tomave republicano, porque en otro Cuadro de 1833 aparece ya como vendedor de 70 marcos semanales al Banco de Rescates, y comprador de 44 libras de azogues consumidos por semana. Los otros "azogueros" de Porco en 1833 son Pedro Malpartida y la Testamentaria de Uzín (a quienes volveremos), y un tal Andrés Argüelles. ANB MH t. $35 n^{\circ} 8$ (TGM recibidas). Banco Nacional de Rescates, 3.vii.1833. Publicado en Platt 1996, Cuadro 10. horneros que se renovaban cada dos días (los turnos eran de 48 horas, aunque puede suponerse que hubo turnos de tres en tres dentro de cada grupo de seis). Después se beneficiaban en ocho fondos de cobre construidos entre 1836 y 1842 , cada uno atendido por un solo peón, que trabajaba seis días en la semana. Las lavas (con la que se separaba la pella, o amalgama, de la ganga) se hacían dos veces por semana, el jueves y el sábado, y estaban presentes los capitanes de molienda y hornos, y el beneficiador de hornos. El establecimiento también mantenía una fundición de cobre, porque los fondos de cobre sólo duraban dos meses. Aquí trabajaba un fundidor y tres peones. Según este recuento, firmado por Juan Romero el 28 de marzo de 1843 , Figueroa empleaba más de 70 trabajadores, aunque en la Tabla 2 se le asignan 40 solamente; debemos suponer que muchos realizaban más que una tarea.

En San Baltasar de Charque, por otra parte, los socios Ignacio G. Ortega y Juan Romero producían dos cajones semanales de metales brozas (bronces) de una sola mina en explotación; se quejaban de la dureza de las cajas. Se empleaban 61 trabajadores que trabajaban "nueve mitas sus dos noches de dobla" durante la semana. Sus máquinas de molienda consistían en dos rastras y tres cedazos, que trabajaban día y noche con ocho trabajadores dando siete cajones de harina cernida. Hubo cuatro hornos para quemar los negrillos, donde se empleaban nueve trabajadores, y una fundición de cobre con tres trabajadores donde se fundían los diez fondos; éstos trabajaban diariamente con 15 trabajadores.

Según Clemente Figueroa, "en [Tomave] se trabaja con los del país, y concurre muy poca forastera"; o sea, con indios tributarios locales que practicaban una economía vertical, ausentándose "por tres o cuatro meses a las fronteras de la ciudad Sucre por víberes". Igualmente estacional fue la oferta de combustible y de agua para las máquinas. Estas consideraciones deben guiar la lectura de la Tabla 2 en lo que toca a Tomave. También se contaba con los indios tributarios para el transporte de los minerales, la leña y la sal. En el caso de Santa Bárbara, el mineral se bajaba por los indios de Tolapampa en tropas de llamas desde las cancha-minas hasta la hacienda de beneficio; y se les pagaban dos pesos en dinero por cajón de 50 quintales ( 1 quintal $=1$ carga de llama). Es evidente que era esencial la concurrencia indígena, presionada por la necesidad de pagar sus tributos. 
El consumo de sal en Santa Bárbara fue de 200 quintales anuales; en San Baltasar fue de 150 quintales (= viajes de llama). Se compraba a 2 reales por quintal y se traía por los indios salineros desde "la Laguna de esta comprensión" (el Salar de Uyuni) a una distancia de 15-16 leguas. Por otra parte, la leña consumida en Santa Bárbara era de 20.000 cargas, pero en San Baltasar llegaba a 60.000 cargas. Esta diferencia se debe, por lo menos en parte, a que González de Ortega y Romero tenían cuatro hornos de quemar en San Baltasar, en comparación con los dos de Figueroa en Santa Bárbara; y diez fondos de cobre, en comparación con los ocho de Santa Bárbara. Probablemente los hornos y fondos adicionales de San Baltasar también se usaban por sus trabajadores, o por otros azogueros que carecían de ellos; cabe preguntar quién proporcionaba la sal para estas hornadas y fondeadas.

\begin{tabular}{|c|c|c|c|c|c|c|c|c|c|c|c|}
\hline 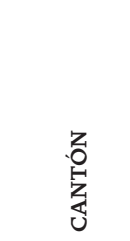 & 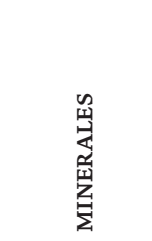 & 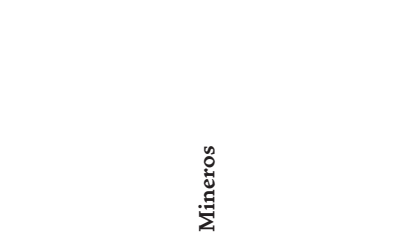 & 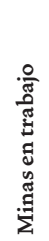 & 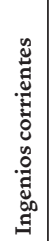 & 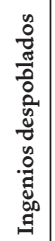 & 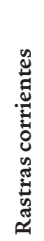 & 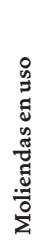 & 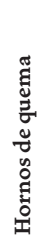 & 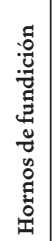 & 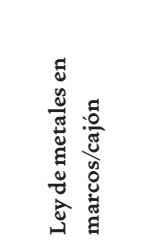 & 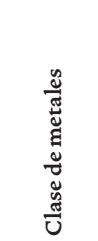 \\
\hline \multirow[t]{17}{*}{ Tomave } & Tomave & José Figueroa & 2 & & & 2 & 2 & 2 & & 30 & negrillos \\
\hline & & Bernardo Tardío & 1 & & & & & & & 70 & mulatos \\
\hline & & Juan Romero & 2 & & & & & & & en diligencia & \\
\hline & & Eusebio Choqueribi & 1 & & & & & & & 50 & pacos \\
\hline & & Ramón y Manuel Dionicio & & & & & 1 & & & & pacos \\
\hline & & Manuel Pascual Suazo & 1 & & & & & 1 & & 50 & pacos \\
\hline & & Ysidro Velarde & 1 & & & & & & & 40 & \\
\hline & & Manuel Gonsalez & 1 & & & & 1 & 1 & & en diligencia & \\
\hline & & Manuel Arroyo & 1 & & & & 1 & 1 & & & \\
\hline & & Andrés Cabrera & & & & & 1 & 1 & & & \\
\hline & & Manuela Córdova & & & & & 1 & 1 & & & \\
\hline & & Subtotal & 10 & & 1 & & & & & & \\
\hline & Cerrillos & Simón Silbestre y Santos Mamani & 3 & & & & 3 & 3 & & & \\
\hline & & Juan Romero (en arriendo) & 1 & & & & 4 & 2 & & 50 & negrillos \\
\hline & Cosuña & & & & & & & & & & \\
\hline & Laranchaguani & & & & & & & & & & \\
\hline & Paca & & & & & & & & & & \\
\hline \multirow[t]{7}{*}{ Tolapampa } & Pulacayo & $\begin{array}{l}\text { José Santiago Portuondo, José Ignacio del } \\
\text { Río. Mariano Ramirez (en sociedad) }\end{array}$ & 2 & 1 & & & 1 & 3 & 3 & 16 & negrillos \\
\hline & Muertos & Gregorio Martinez & 1 & & & & 1 & & & 50 & pacos \\
\hline & Ubina & & & & & & & & & & \\
\hline & Tayacmayo & Manuel Gallo & 1 & & & & 1 & & & 60 & pacos \\
\hline & San Juan Casa & Vicente Mendez & 1 & & & & & & & 25 & pacos \\
\hline & & $\begin{array}{l}\text { Francisco Palomino J.B. Isarraga, } \\
\text { N. Jimenez (en sociedad) }\end{array}$ & 2 & & & & & & & & \\
\hline & Cisneros & & & & & & & & & & \\
\hline Coroma & Carguaycollo & & & & & & & & & & \\
\hline
\end{tabular}

Tabla 3. Minería del asiento mineral de tomave,1836.

Fuente: ANB MH TGM t.52 nº 10. Estado que presenta el Ylustre Directorio del Asiento Mineral de Tomave. Potosí, 10.ii.1836. 
La leña se traía por los llameros desde hasta cinco leguas de distancia, y en Santa Bárbara se pagaba la mitad en plata y la mitad en género. Pero el costo de cada carga de llama se pagaba por distancia y, evidentemente, la carga de leña costaba mucho menos que la carga-quintal de sal. En todo caso, con semejante demanda los llameros deben haber ganado muy por encima de sus necesidades tributarias.

\section{* La sociedad mineralójica Huanchaca}

Ahora bien, en la Provincia de Porco también trabajaban dos azogueros medianos con giros importantes y considerable influencia política. El más conservador, Pedro Malpartida, dirigía tiránicamente las minas, el ingenio y casi todo el cantón de Siporo, en rivalidad con otra empresa local, Charichari, creada por el último Subdelegado colonial y primer Gobernador republicano de la Provincia, Leandro de Uzín. Por otra parte, al otro lado de la Provincia hubo un azoguero de ideas más "modernas", Mariano Ramírez y socios, fundadores de la Sociedad Mineralójica Huanchaca en el distrito minero de Tomave. En los demás minerales de la Provincia, como ya hemos visto en los casos de Carguaycollo y Tomave, la actividad minera en 1842 estaba en pequeña escala. La comparación con las empresas medianas de Ramírez y Malpartida nos permitirá comprender mejor el pensamiento político-económico, las formas de capitalización, la organización técnica del trabajo y las relaciones productivas en la Provincia durante las primeras décadas republicanas.

A mediados del siglo, el ingenio de Siporo y las minas de Machacamarca todavía eran más productivos que Huanchaca y Pulacayo, aunque las relaciones laborales de Malpartida eran conflictivas, a diferencia de las de Huanchaca, donde Ramírez y sus socios habían pensado con cuidado el problema laboral desde el principio. Pero a pesar de sus diferencias, Ramírez y Malpartida estaban de acuerdo sobre una cosa: fueron los azogueros los que mejor conocían sus propios intereses y los de su gente, y ellos solos deberían encargarse de su corrección, no los jueces ni las autoridades estatales.

Veamos primero la empresa de Mariano Ramírez, quien trajo sus conocimientos mineralógicos desde Chichas (Atocha) más al sur, donde fue residente por varios años. En Huanchaca instalaba fondos de cobre para el beneficio por hervición y contrataba con los curacas de las comunidades indígenas de Río Blanco (Chichas) para que trajesen a sus indios tributarios a trabajar en las tareas de molienda y cedaseo de Huanchaca. ${ }^{27}$ Su régimen combinó una comprensión de los recursos humanos del país con la voluntad de planificar una empresa cuyos frutos no se verían sino después de su propia muerte. En cuanto Director y Administrador General de la Sociedad de Huanchaca, situada en el Cantón de Tolapampa a cuatro o cinco leguas del Curato, Ramírez dió en 1842 una respuesta detallada - en realidad, dos informes - al Ministro de Hacienda. Complementada con otra documentación (notarial y periodística), su respuesta nos permite comprender los inicios distintivos de lo que sería, en manos del patriarca minero don Aniceto Arce, el asiento mineral más importante del país en la segunda mitad del siglo XIX (Mitre 1981).

\section{La formación de la Sociedad}

Ramírez empieza acordándose del estado de abandono en que se encontraron los cuatro cerros minerales de Tolapampa - Pulacayo, Cozuña, Muertos y Ubina - cuando empezó a trabajar en Huanchaca. El único minero fue un español, Francisco Palomino, quien ya había invertido 3.000 pesos en Ubina, pero tuvo que abandonar el trabajo. Hubo, en aquel momento, nueve ingenios arruinados donde se beneficiaron los metales de Ubina en tiempos coloniales: dos en Huanchaca, uno en Mactuyo, uno en Cari, dos en Chifloyo, dos en Challa y uno en Ticaguani. Todos los cacchas se habían ausentado a los minerales de Chichas, y otras partes, por no haber quien les diese adelantos para trabajar en Ubina. Los indios de Tolapampa, mayormente llameros, quienes antes se acostumbraban a acarrear metales, sal y combustible para el beneficio, ahora llevaban su sal a grandes distancias por falta de trabajo en Ubina, e incluso vendían sus animales para pagar sus contribuciones tributarias y parroquiales.

Mariano Ramírez era nativo de Tolapampa, habiendo nacido en Ubina, con experiencia minera previa en Ubina, Potosí y Chichas. Desde su domicilio en Atocha, cantón

\footnotetext{
${ }^{27}$ Mediante estos dos procesos se convertía el mineral crudo, bajado de la cancha mina, en harina mineral pulverizada con morteros y tamizada con cedasos, lista para ser beneficiada.
} 
de Portugalete, empezó su trabajo en el cerro de Pulacayo haciendo limpias y recortes en varias minas abandonadas. En 1833 se asoció con dos amigos, el comerciante chileno José Santiago Portuondo, y el minero orureño José Ignacio del Río, ${ }^{28}$ para comprar el ingenio de Huanchaca, en estado arruinado, por 550 pesos de su anterior dueño el Coronel Manuel Antonio Tardío. ${ }^{29}$ Así se formó la Sociedad Mineralójica Huanchaca. Cada socio puso una tercera parte del precio de compra del ingenio, y contribuyó con una primera cuota de 500 pesos a los trabajos dirigidos por Ramírez. Ramírez y del Río pondrían "su personal trabajo en el desempeño de minas e ingenios", y Portuondo sería el representante de la Sociedad en Potosí. ${ }^{30} \mathrm{El}$ ingenio se compró "con sus usos, costumbres y servidumbres, pastos y terrenos, relaves y calsines..."; e incluía también una capilla arruinada, que en 1842 se había reconstruido, junto con un Pantéon grande, en un lugar apartado de los ingenios.

El capital inicial de los tres accionistas se complementó con préstamos hasta 1837, año cuando lograron "arreglar" el trabajo de minas e ingenios. El mismo año murió Portuondo; en su Testamento dijo haber invertido mas de 11.000 pesos en la empresa, bajo fianza de sus consocios José Ignacio del Río y Mariano Ramírez. Su acción fue heredada por su hermana Tadea del Carmen Portuondo de Osio, azoguera de Aullagas. ${ }^{31}$ En 1851 vendería su acción a del Río y Ramírez por 28.000 pesos. ${ }^{32}$

\section{Trabajos preliminares}

Las inversiones de la Sociedad se dedicaron, primero, a habilitar dos represas y construir una nueva, llevando el agua por acequias desde una ciénaga cercana. El agua se acumularía en las tres represas durante 18 horas; sólo

\footnotetext{
${ }^{28}$ Ver el Testamento de Ignacio del Río, donde afirma haberse casado con la finada María Josefa Sanz de Cespedes, con quien residía en la Calle de Santa Teresa (o Ayacucho) en Potosí. Fue Administrador de los intereses mineros de Martín Jaureguí (situados especialmente en Aullagas, Provincia de Chayanta) entre 1826 y 1833 , año de la muerte de Jaureguí. AHP EN 237 ff.179v-186, 27.vii.1857.

${ }^{29}$ AHP EN 272, f.306v, 30.ix.1833. Para la actuación posterior de Tardío en el Cerro de Porco, ver la sección "La minería de la Provincia de Porco en 1850 ", en este mismo artículo.

30 AHP EN 272, f.306v, 30.ix.1833; id., f.328, 17.xii.1833.

${ }^{31}$ AHP EN 277, f.260, 18.xii.1837.

32 El Celaje t.2 no 13, Potosí, 2.ii.1852.
}

hubo suficiente para dar impulso a las ruedas de los dos ingenios reconstruidos, además de tres rastras, durante seis horas diarias. Desde 1837 hasta 1842 se molían de seis a ocho cajones semanales de metales negrillos.33 Para la quema de las harinas de mineral se construyeron cuatro hornos de reverbero, con capacidad para 10 quintales. Después de quemarse durante ocho a diez horas se depositaban las harinas tostadas en cuartos al lado del departamento de beneficio, que se realizaba por hervición en fondos de cobre dos veces al día. Completado el beneficio, se descargaba la amalgama, puesto en "tarros de madera", a un gran lavadero, donde se realizaban dos lavas por semana, miércoles y sábado. Finalmente, las piñas se quemaban "en baúles", 34 con ucha y taquia por la escasez de carbón, para quitar cualquier remanente de azogue.

Los trabajos mineros de la Sociedad se concentraron en dos minas del cerro de Pulacayo: Esperanza y Tajo. La mina Esperanza estuvo llena de humbe, cegada de caja, y abandonada desde 1780. Ramírez y sus socios la limpiaron hasta la profundidad de 250 varas por debajo de la lumbrera, avanzando del este al oeste por 400 varas. En esa profundidad se agotaron los metales sin dar en agua, y se calculaba que los restos de metal durarían apenas cuatro años. Se producían tres cajones semanales de metales brosas. ${ }^{35}$ La mina Tajo fue profundizada por cuatro años sin dar más que tierra sin valor (bazofía) hasta que a las 80 varas de profundidad se alcanzaron metales que duraron hasta la profundidad de 157 varas, cuando daba en agua. Sus metales fueron también brosas, que se beneficiaban con azogue, separándose las ligas ${ }^{36}$ para ser fundidos. La explotación semanal era de cuatro a cinco cajones.

Las brosas mezcladas de ambas minas tenían una ley de 22 marcos por cajón, que en esa fecha valía de 176 pesos a ocho pesos / marco en el Banco de Rescates de Potosí.

33 Pero cf. f.32v: “... se muelen de 8 a 10 cajones de metal negrillo ... y por un cómputo aprocsimado da la Molienda 10 cajones semanales cernidos".

34 No conozco el significado exacto de la frase "en baúles", aunque se intuye el uso de un alambique para recuperar el azogue volatilizado.

35 "Brosa, metal prócsimo á la guia de una veta que tiene menos luz aunque á veces útil” según el "Diccionario de Minería", en Prontuario de los juicios ... Chuquisaca 1830 (BNB M 531).

${ }^{36}$ Metal fundente. 
Ramírez calculó que los costos de extracción por cajón eran 50 pesos, y los de beneficio 100 pesos. Los 26 pesos de ganancia, junto con las utilidades de la pulpería, se reinvertían en las mismas minas, y en la construcción de dos socavones nuevos: uno en Pulacayo fue para cortar las vetas y desaguar la mina de Tajo, con un costo estimado de 60.000 pesos sobre seis años; y el otro fue en el cerro de Ubina, iniciado en 1841 y destinado a desaguar las minas aguadas desde hacía más de 47 años, con un costo estimado en 100.000 pesos durante ocho a doce años. Éstos se consideraban "obras para el futuro, y acaso no veamos el fin ..." No se pagaban dividendos a los accionistas, quienes seguían el trabajo "alimentados con la esperanza de mejora en la ley de los metales".

La división de todos los minerales en brosas para amalgamación con azogue, y ligas para ser fundidas, se refleja en la existencia, al lado de los dos ingenios de Huanchaca donde estaban los fondos de cobre, de un "departamento" especial para la fundición del metal ligoso, con almacenes, hornos de fundir y refinar. Este departamento sólo funcionaba dos meses por año por la escasez de leña.

\section{Los trabajadores}

A los llameros que vivían alrededor de Huanchaca se les había dado mas de 1000 costales para que ayudasen a bajar los minerales de las dos canchaminas de Pulacayo a los ingenios en Huanchaca. Los pocos que no tenían llamas se empleaban en cortar leña. Pero el grueso del trabajo tuvo que venir de lugares mas lejanos.

Los trabajadores de las minas procedían de Potosí, Portugalete (Chichas) y "otros minerales", y se pagaron las deudas acumuladas en su lugar de procedencia antes que pudiesen arraigarse en Huanchaca. Algunos obreros temporales también acudían desde Tomave y Calcha. Los barreteros ganaban seis a ocho reales por día, los pongos ocho reales, los ponguillos cinco reales, los apires cuatro reales, y los chivatos (muchachos) dos a tres reales. Las mujeres "palliris" ${ }^{37}$ también ganaban dos a tres y medio reales "según su trabajo y conciencia de los mineros y canchamineros", quienes informaban de su trabajo cada domingo al Administrador. Efecti-

37 Pallay (Que.) = recolectar. -iri es agentivo aymara. Las "recolectoras" de metal en los desmontes eran generalmente mujeres. vamente, todos los domingos se proclamaban públicamente los jornales y los gastos a crédito de todos los operarios; después se procedía a adelantarles dinero y comida para la próxima semana, y se pagaba a cada uno su balance de la semana vencida, la mitad en plata y la mitad en "ropa para vestirse él y su familia".

En las dos minas de Pulacayo se empleaban 148 hombres y mujeres, y 163 en el nuevo socabón, además de 41 en el nuevo socabón de Ubina. Para el trabajo de molienda en Huanchaca, con sus dos ingenios y cinco rastras "de nueva idea" ${ }^{\prime 8}$, se hacían contratas desde 1838 con los curacas indígenas de la quebrada del Río Blanco en la Provincia de Chichas a 25 leguas de distancia. Según la contrata, los curacas, alcaldes y segundas debían poner 24 tributarios cada tres semanas para trabajar como "cedasiris" y "mortiris". 39 Se pagaban dos reales a cada autoridad indígena, y dos reales "de gratis" a cada peón por su venida, con la condición adicional de abonarles su tributo íntegro en dinero. El tributo se pagaba en un solo vale, que se llevaba por los curacas al final de cada relevo para ser presentado en Potosí. El jornal de los peones se calculaba a cuatro reales, y la sobra de su jornal se pagaba en ropa a cada individuo. Cuando llegó el relevo el día de domingo tres semanas más tarde, se adelantaba plata y comida a los recién llegados a las nueve de la mañana, y a los que salían se les pagaba a las dos de la tarde, para que pudiesen volver cargando sus camas en los mismos buros que habían traído los equipajes de los nuevos. Ramírez expresó preocupación por la salud de los peones de molienda, "por el polbo del metal, por el Arsénico, y Antimonios que contiene el metal negrillo; pero es tal la virtud del agua de ese Río, que luego que llegan a sus casas, y toman la chicha y agua, son purgados" (...).

Los 17 peones que trabajaban en Huanchaca en los hornos de quema, donde se tostaban los metales negrillos, eran "algunos de Challapata y otros de Chichas, que siempre se remudan"; ganaban un peso por jornal que se pagaba la mitad de plata y la mitad en género. Los 43 peo-

38 "Muelen en sus ruedas orizontales con la misma agua de los Yngenios" (loc. cit.).

39 Los cedasiris eran quienes cernían el metal triturado para producir una fina harina mineral. Los mortiris cuidaban las almadanetas de los morterados, suministrando nuevas piedras minerales para ser trituradas. 
nes del trabajo de beneficio con los fondos de cobre eran de Calcha, Challapata y Quirve; se les pagaba cinco reales por jornal de la misma forma. En los dos o tres meses del año cuando funcionaba la fundición de platas "ligosas", se empleaban otros 15 hombres; $y$ cuatro veces por año se fundían los fondos de cobre con el trabajo de cuatro hombres. Estos peones, como los albañiles y canteros, fueron pagados "según su capacidad o abtitudes" mitad en plata y mitad en género. Finalmente los otros dependientes y artesanos se pagaban "según convenio, y si sacan algo de jénero es porque lo piden y a ninguno se les obliga”.

El resumen general de los trabajadores de la Sociedad Huanchaca en 1842 es como sigue:

\begin{tabular}{|c|c|c|}
\hline Minas y socabón de Pulacayo & & 163 \\
\hline Ingenio de Huanchaca & Molienda & 43 \\
\hline & Hornos de quema & 17 \\
\hline & Fondos de cobre & 33 \\
\hline & Fundiciones de fondos & 4 \\
\hline & Fundiciones de plata & 15 \\
\hline Otros operarios & & 25 \\
\hline Socabon de Ubina & & 41 \\
\hline TOTAL & & 341 \\
\hline
\end{tabular}

Tabla 4. Los trabajadores de la Sociedad Huanchaca en 1842.

Mariano Ramírez calculaba en 600 las almas constantemente residentes en Huanchaca y Pulacayo, cifra que subía a 800-1000 en ciertas épocas del año, sin contar con los que se ocupaban en el transporte de metales, de sal y de combustible, y omitiendo a las 70 a 80 almas existentes en la nueva empresa mineral de Ubina a doce leguas del ingenio. En Huanchaca se habían formado oficinas, talleres, almacenes y casas para la población.

En cuanto a los transportistas de minerales, sal y combustible, ya hemos visto que los llameros de Tolapampa se dedicaban principalmente a las bajas de metal, actividad que les permitía reunir el dinero necesario para pagar sus tributos. Cada año se ocupaban más de 100 bajadores: 50 cargas de llama formaban un cajón de mineral (una carga = un quintal), y el cajón se pagaba a cuatro pesos por traerlo desde Pulacayo (dos leguas de distancia) y a 12 pesos desde Ubina (12 leguas). Algunos tolapam- pinos también contribuían a suministrar sal, recibiendo dos reales por quintal a contado. Pero los llameros de San Cristobal de Lípez trajeron sal por igual precio desde Cañisa, al lado del salar de Uyuni, y a ellos se les pagaban los dos reales mitad en género y mitad en plata. El consumo total de sal fue 99 quintales por semana: 72 quintales en los hornos de quema y 27 en el beneficio de fondos.

Finalmente, se consumían en el establecimiento 3816 cargas de leña y uchu ( $=i c h h u$, paja brava de la puna), una mitad en los cuatro hornos de quemar, y otra mitad en los fondos de cobre. Se pagaba un peso por 12 cargas, sumando 318 pesos en total, sin contar lo gastado en fundiciones de plata y fondos. Es de notar que el pago fue principalmente en género.

\section{El salario}

Ahora bien, Mariano Ramírez insiste que, a diferencia de muchos otros centros mineros, a él no le faltaban trabajadores, hecho que atribuye a los precios más "equitativos" de los efectos dados por anticipo o en pago parcial del salario. Esta práctica acertada se había acordado entre los tres socios fundadores de la Sociedad al iniciar el trabajo. El resultado fue que la gente venía desde Challapata, Chichas y Potosí "sin buscarlos". Así, podemos comprender también la huida de la gente de Chichas sin pagar sus deudas, no tanto como una muestra de inmoralidad obrera (como decían los azogueros de Chichas), sino como un intento de trasferirse a un centro minero donde las tasas de cambio de los efectos eran más favorables para el trabajador. De hecho, Ramírez afirma que sólo aceptaba a los candidatos una vez canceladas sus deudas pendientes. Así, no necesitaba emprender búsquedas ni enganches para abastecerse de mano de obra: la forma del salario, y la tasa del cambio para los efectos, eran suficientes para atraer a los trabajadores necesarios.

Esta afirmación tiene implicancias importantes para el estudio del salario minero. Vemos que el pago de parte del salario en efectos, a menudo considerado abusivo por la historiografía minera, fue en este caso más bien un aliciente para el trabajador. Los conflictos y las quejas que surgían en otros centros (por ejemplo, en Siporo) deben atribuirse, de acuerdo con esta evidencia y como veremos más abajo, no tanto al pago de efectos en sí, sino a las tasas abusivas del cambio y la proporción exagerada del salario que se pagaba en género. 
Los efectos vinieron a Tolapampa contratados por Ramírez y sus socios en Chichas, Potosí y Oruro. De Chichas (y seguramente de Tarija y Argentina también) llegarían "matanzas, cueros, sebos, maices y harinas"; de Oruro vendría la ropa de la tierra, y - seguramente através de los arrieros de Challapata que servían de intermediarios con los Yungas de La Paz - la coca. De Potosí se traerían con cada remesa algunos efectos ultramarinos, sobretodo el azogue.

\section{Producción y planificación}

Entre 1837 y 1842 la Sociedad había producido un total de $48.213 \frac{1}{2}$ marcos en piñas y planchas, rescatadas en los Bancos de Potosí y Oruro. Por otra parte, Ramírez se queja de la escasez y el alto precio del azogue, como todos los demás azogueros, y también del excesivo gasto en combustible y cobre necesarios para mantener el sistema de beneficio con fondos. Estos gastos no se imponían en el sistema de repaso en buitrón, aunque los gastos del repaso eran mayores por el número de los repasiris necesarios. Ramírez cifra sus esperanzas a corto plazo en el buen éxito que resultara de sus pruebas con el sistema de beneficio por tónel, una referencia al nuevo método patentado en Chile por el escocés John Stevenson en $1835 .{ }^{40}$ A largo plazo, el futuro dependía de los resultados de los dos socavones.

Aparte de la importancia que atribuye a la tasa de cambio "equitativa" de los géneros, es también notable el énfasis que Ramírez pone en la ayuda de la Divina Providencia, los esfuerzos que hace para establecer una nueva capilla adecuada para los trabajadores, además de un nuevo Panteón, y su reconocimiento que los mejores resultados de sus esfuerzos quizás sólo aparecerían después de su muerte. Además, la bebida alcohólica fue prohibida en su establecimiento, aunque no faltaba la internación clandestina. Quizás fue como parte de esta actitud ético-religiosa que Ramírez dijo haber entablado su giro minero sin haber pedido ningún préstamo, ni del Banco de Rescates ni del Banco de Habilitaciones. Tampoco había pedido la ayuda del Gobernador de la Provincia de

\footnotetext{
${ }^{40}$ El método de Stevenson, que consistía en una cruz de hierro que giraba contra la base de un fondo de hierro, fue usado también por Calixto Yañez en San Joaquín (Chichas) y por Tudó en la Rivera de Potosí. Ver El Restaurador (Sucre), V.65. 1.vii.1843. Cf. Platt 1998-99.
}

Porco para "estimular" a los curacas a entregar tributarios al trabajo, como lo hacían otros azogueros. Así, Ramírez pudo distanciarse de la "cripto-mita" organizada "por convenio" en Chichas, que a menudo requería la intervención del Gobernador de Chichas (Platt 1998-99). Sin embargo, el Gobernador de Chichas sabía muy bien que el dinero para los tributos $-\mathrm{o}$ a veces las piñas, cuyo valor los Curacas debían cancelar con hasta cuatro años de trabajo rezagado - salía principalmente de Huanchaca. En este caso, el pago y los anticipos de tributo indígena al gobierno se realizaban gracias al crédito ofrecido por el minero.

Finalmente, Ramírez se une a la opinión común de los azogueros a favor del castigo de los trabajadores "viciosos" o insolentes directamente por su patrón. La prohibición legal de esta práctica había conducido, según Ramírez, a que "si son recombenidos, todos [los trabajadores] son D.D. que citan códigos" - probablemente una referencia al conocimiento de las provisiones del Código Santa Cruz por los trabajadores. El reclamo se inserta dentro del modelo patriarcal de la relación entre patrón y trabajadores favorecido por los azogueros. El comentario de Ramírez también indica el conocimiento por los trabajadores de sus derechos legales, y su capacidad de citar las leyes al intentar protegerse contra la corrección patronal, como veremos en el caso de Siporo.

\section{Fin de la primera fase de la Sociedad Huanchaca}

La primera fase de la Sociedad Huanchaca puede concebirse como extensiva desde el año de su fundación en 1833 hasta la venta de sus acciones en 1856 y 1857 por los socios fundadores, Mariano Ramírez e Ignacio del Río. Un reportaje sobre la empresa publicado en El Minero (cuyo redactor fue Aniceto Arce, concuñado de Mariano Ramírez $)^{41}$ muestra que en 1856 funcionaban dos ingenios y tres rastras con agua recogida en las tres represas, o estanques, alimentados por varios vertientes a través de la acequia que ahora extendía por "cuatro leguas con calzadas de piedras labradas y tres túneles, importando toda la obra 35.000 pesos".

Para el beneficio de los metales negrillos de Pulacayo, seguían usándose los fondos de cobre. Se comentaba la presencia de seis "malos hornos de reverbero" para la

${ }^{41}$ ElMinero no ${ }^{19}$, Potosí, 1.vi.1856. 
tuesta de los metales (dos hornos más que en 1842; cada hornada tardaba de ocho a diez horas); y diez paradas de fondos ( 20 fondos) donde se amalgamaban diariamente de 60 a 100 quintales, con una ley de 20 a 22 marcos por cajón de 50 quintales.

En el cerro de Pulacayo se había completado el socavón bajo construcción en 1842. Tenía ya 800 varas de largo, con 230 varas de carril. ${ }^{42}$ Cuatro vetas se habían cortado - Tajo, Corpus, Ánimas y Santo Tomás - , explotándose solamente la primera "que sin duda es el filón más poderoso que se conoce en Bolivia, teniendo por término medio cuatro pies de ancho y en estensión considerable se ensancha hasta 21 pies de metal puro". La ley era de 40 marcos/cajón, aunque en la amalgamación sólo resultaban 20 a 22 marcos/cajón (como en 1842). Ya había dado sus frutos por lo menos una de las iniciativas tomadas en la década de 1830 por Ramírez.

También habían nuevas construcciones y sembradíos en las haciendas de Irpa y Challa; y las minas de Ubina estaban en punto de habilitarse mediante el segundo socavón labrado desde 1841 por debajo del antiguo socavón aguado. Estas minas sostendrían la producción de Huanchaca en las últimas décadas del siglo. En ambos socavones se habían colocado en 1856600 varas de carril [de madera] (siguiendo el ejemplo de la Sociedad Ancona en Carguaycollo) y se buscaba una comunicación entre los dos para completar el desagüe.

Una inspección de los libros de cuenta de la Sociedad en 1856 mostró que, desde sus inicios, se había producido una cantidad de plata valorizada en mas de 3 millones de pesos, con una contribución al erario nacional de 800.000 pesos, "sin que los empresarios hubieran conseguido un solo dibidendo en recompensa de su laborioso y asiduo trabajo de 24 años". Se reconoce aquí la política de reinversión de ganancias seguida por Ramírez y sus socios desde los inicios de la Sociedad.

En 1856 se comentaría nuevamente el hermoso templo de la empresa, y "un cementerio o enterratorio que podrían lucir en nuestras Ciudades". Pero la recompensa material para Mariano Ramírez e Ignacio del Río sería

\footnotetext{
${ }^{42}$ El uso de carriles de madera se había introducido antes por José Avelino Aramayo en Carguaycollo.
}

el valor de las cuatro acciones que cada uno poseía entre un total de doce acciones que conformaban en aquel momento el capital de la Sociedad. El mismo año Ramírez vendió dos acciones a Aniceto Arce por 40.000 pesos $^{43}$ (más tarde aumentado a casi 50.000 pesos) ${ }^{44}$, y en 1857 las otras dos a Mariano Ipiña (representado por José Avelino Aramayo) en 50.000 pesos. ${ }^{45}$ También en 1857 Ignacio del Río vendería sus cuatro acciones en 25.000 pesos cada una a Mariano Ipiña y Avelino Aramayo. El resultado fue casi 100.000 pesos para cada uno de los dos socios originarios. ${ }^{46}$

Así terminó la primera fase de la explotación de Huanchaca, construida principalmente mediante la reinversión de las ganancias líquidas de la empresa sin pago de dividendos ni recurso a capitales extranjeros. Entre los otros factores responsables para el éxito de la empresa - además de la existencia de los mismos depósitos minerales - deben destacarse, primero, la acertada política salarial de la empresa comentada líneas arriba, que garantizaba un suministro adecuado de brazos; la oferta tributaria de los ayllus indígenas de Chichas en el morterado y el cedaseo, además de los llameros indígenas que bajaban el metal de la canchamina al ingenio, y traían la sal y el combustible para el beneficio; y tercero, la contribución del Padre Alonso Barba y sus sucesores metalurgos del siglo XIX, quienes hicieron posible la instalación del método "por cocimiento" en fondos de cobre ${ }^{47}$ como la base del beneficio de la mayor parte de los metales explotados. Los fondos seguirían usándose en Huanchaca hasta la introducción de un nuevo variante sobre la idea original de Barba, las "tinas" inventadas en 1876 por el ingeniero alemán Carlos O. Francke (Platt 1998-99).

\footnotetext{
43 AHP EN 282 f.80, 6.vi.1856. En 1856 los otros accionistas, aparte de del Río, eran Mariano de Argandoña (cuñado de Ramírez), Mariano Revilla y Juan Elías de Duo.

${ }^{44}$ AHP EN 383A f.6o, 8.v.1857; cf. EN 386 f.196, 13.ix.1860.

${ }^{45}$ AHP EN 282 f.91, 17.vi.1856.

${ }^{46}$ AHP EN 383 ff. 60 (8.v.1857) y 76v (12.vi.1857).

47 En 1864 Adolfo Fauçon, un "francés americano" avecindado en Argentina, fue contratado para construir en el ingenio de Chaca de la Rivera de Potosí "una pila, con fondo de cobre por hervición", además de dos hornos de fundición y otro de quema, para beneficiar "los metales que a prueba se traigan del Cerro de Pulacayo". Se trata de una de las pocas referencias que conocemos a la construcción de fondos de cobre en la Ciudad. AHP EN 394 f.23, 16.i.1864.
} 


\section{* El “despotismo sultánico” en Machacamarca: Siporo, Bartolo y CHARICHARI}

El mineral de Machacamarca, situado en el río de Milluni, se compone - según el informe del Ciudadano Pedro Malpartida, conductor de la hacienda de beneficio de Siporo - de dos cerros "opulentos" nombrados Pobres y San Cristóbal. En estos cerros habían en 1842 varias minas en explotación reclamadas por dos partes: la Testamentaria de Leandro de Uzín, cuyo ingenio de Charichari se situaba en la quebrada de Tacobamba; y el mismo Pedro Malpartida, quien arrendaba Siporo con sus minas del ex-Marqués de Cásares, el dueño ausente Manuel José de Peralta. ${ }^{48}$

Pedro Malpartida había arrendado el ingenio de Siporo desde $1820 .{ }^{49}$ Pero en 1819 ya aparece como dueño de un ingenio de tres cabezas en Machacamarca, al mismo tiempo que Siporo se encuentra aún en posesión del conductor anterior, el Coronel Indalecio González de Socasa (Aillón 2009) $)^{50}$. Se trata, probablemente, del ingenio que Malpartida tenía como propiedad personal en Bartolo, y que seguía trabajando en 1842. En 1819 Malpartida también se declara como dueño de una hacienda llamada "Oveja Cancha" en la doctrina de Puna, capital de la Provincia de Porco; y de una "casa del Tambo" en la "calle de las Canchas de la Recoba" en Potosí. ${ }^{11}$ En 1830 Malpartida renovó por 9 años más ( 5 forzosos) en 5.000

${ }^{48}$ Para el mayorazgo de Siporo, fundado en 1748 por Rosa Peralta y Moscoso, ver Crespo Rodas et.al. 1984:103-5. Los mayorazgos y los marquesados fueron abolidos por el gobierno de Andrés Santa Cruz en 1833 .

${ }^{49}$ AHP EN 202A, f.140r, 20.vii.1820. En 1799 el arriendo estuvo en 8.500 pesos: la caída a $58 \%$ de su valor anterior representa una variación relativamente leve en comparación con la de muchos otros ingenos arruinados que se arrendaron a principios de la República. Ver Crespo Rodas et.al. 1984:113.

${ }^{50}$ AHP EN 198, f.787v, 25.vi.1819. Indalecio Gonzalez de Socasa había arrendado Siporo del Marqués de Cáceres desde 1813, por medio del apoderado del Marqués, el realista español José María de Lara, quien en 1835 se había convertido en el Ministro de Hacienda de Andrés Santa Cruz.

${ }^{51}$ AHP EN 200, f.608r-609r, 31.vii.1819. "Lista nominal de los asogueros que se han presentado en este Oficio de Minas de mi cargo expresando las cabezas de Ingenio que trabajan y las fianzas que dan ...". pesos anuales ${ }^{52}$ el mismo arriendo que había pagado desde 1820,53 cuyo monto refleja el estado rentable del beneficio en Siporo.

Leandro de Uzín, azoguero de Charichari y con minas en Machacamarca colindantes con las de Malpartida, había mantenido una sociedad minera conjuntamente con Malpartida desde 1820, en base a los ingenios de Charichari y Siporo. Al disolverse la sociedad en 1830 , Malpartida se comprometió a pagar a Uzín 130.000 pesos en recompensa por el capital que éste había introducido. Uzín expresó su deseo de mantener la "afectuosa reciprocidad en que hasta ahora se ha vivido ... con su socio Malpartida". Las empresas de ambos se separaron, y Charichari se quedaba como la exclusiva propiedad de Uzín, junto con dos minas, Santiago y La Pasión. ${ }^{54}$

Estas dos minas seguían explotándose por Leandro de Uzín, con la colaboración informal de Malpartida, hasta la muerte de Uzín el 9 de octubre de 1832. Después de su muerte, los albaceas de Uzín, Juan Mariano de Ibargüen e Inocente Agustín Telles, ${ }^{55}$ iniciaron juicio contra Malpartida por los miles de pesos adeudados, que hubiera llegado al embargo y secuestro de los bienes de Malpartida. ${ }^{56}$ Sin embargo, en septiembre 1833 se llegó a un acuerdo sobre las cuentas pendientes, según el cual Malpartida salió debiendo solamente 14.969 pesos 4 reales. ${ }^{57}$ Pocos días después de la transacción, Malpartida a su vez denunció a la Testamentaria de Uzín por haber entrado a una mina suya llamada Guadalupe colindante con La Pasión. Nuevamente se llegó a una transacción, reconfirmando la pertenencia de La Pasión a la Testamentaria en base a un deslinde entre La Pasión y Guadalupe..$^{58}$

Pero Malpartida había puesto sus miras sobre La Pasión. En 1835, Viviana de Uzín, hija de Leandro, inició un nue-

\footnotetext{
${ }^{52}$ AHP EN 356, f.254, 20.x.1830.

53 Crespo Rodas et.al. (1984:114-5).

54 AHP EN 356, f.199, 6.ix.1830.

55 Ibargüen fue español (vasco), Administrador del Banco Nacional de Rescates. Telles fue inventor de una máquina de repaso, y autor de un importante libro de metalurgia (Telles 1831), además de curador y tutor de los hijos de Leandro de Uzín.

${ }^{56}$ AHP EN 270, f.189, 1.ix.1833.

57 AHP EN 270, ff.212-231, 26.ix.1833.

${ }^{5}$ AHP EN 270, ff.239-246, 1.x.1833.
} 
vo pleito contra dos empleados ${ }^{59}$ de Malpartida por haber abierto comunicaciones a la labor de La Pasión "con el objeto de usurpar sus metales". ${ }^{60}$ A lo cual Malpartida contestó denunciando como despobladas las minas de La Pasión y Santiago, y pidiendo restitución de la mina de San Francisco. ${ }^{61}$

La "afectuosa reciprocidad" de antaño entre los socios Uzín-Malpartida estaba en ruinas. Es posible que el deseo de Malpartida de poseer la mina de La Pasión deba atribuirse a un sentimiento de ambición vengativa, producto del juicio abierto en 1832 por los Albaceas de Uzín, y agravado quizás por la abolición en 1833 del mayorazgo de Siporo por el Presidente Santa Cruz. Pero hubo razones materiales también. Pues, el conflicto sobre el deslinde entre las minas de Guadalupe y La Pasión volvió a estallar en 1842, los propietarios y dependientes de ambas empresas rivalizándose en atropellos y propases para ganar al otro en el acceso a una veta rica que se encontraba en boya. Según el Alcalde Veedor de Minas, Eduardo Subieta, comisionado por el Prefecto de Potosí Rafael de la Borda para resolver el conflicto, se trataba de hecho de "una sola mina con dos entradas". ${ }^{62}$ No es de sorprenderse, entonces, que en los informes de 1842 siguen encontrándose inconsistencias y superposiciones en el número de minas reclamadas por ambas partes. En 1842, Malpartida pretendió poseer seis minas correspondientes a Siporo en Machacamarca, junto con otras tres que eran de su propiedad personal; por otra parte, el hijo de Leandro de Uzín, Nazario, le atribuyó cuatro minas solamente, reclamando La Pasión y Santiago para sí.

\section{Las haciendas de beneficio de Machacamarca en 1842}

El ingenio de Charichari perteneciente a Leandro de Uzín, y después de su muerte en 1832 a su Testamentaria, se situaba en la quebrada de Tacobamba a cinco leguas del mineral de Machacamarca. En 1842 tenía un ingenio de cinco almadanetas, y había otro que quedaba sin trabajo "por la escasez de brasos, yndígenas llameros que condu-

\footnotetext{
59 Uno de ellos fue Juan Feraudi, en 1842 Administrador de Cerro y Minas para Malpartida.

${ }^{60}$ AHP EN 275, f.88, 29.v.1835.

${ }^{61}$ AHP EN 206B, f. , 14.vi.1835.

62 AHP PDE 2227 (1843), Sobre inspección y amojonamiento del pozo de ordenanza en las minas de Guadalupe y La Pasión en el mineral de Machacamarca.
}

cen el metal y por el subido precio del azogue". En el ingenio corriente se molían los minerales de calidad brosas, con una producción de 12 cajones semanales y una ley de seis marcos por cajón. También había una rastra corriente, que se utilizaba para moler los metales de alta ley (chaguas), con una producción de dos cajones semanales de metal cernido. Según Nazario de Uzín, la rentabilidad de la empresa dependía de las chaguas "cuya aparición es contingente".

Existía también un horno para quemar los negrillos, que trabajaba periódicamente cuando se había acumulado una cantidad suficiente de estos metales. Pero los Uzín no usaban fondos de cobre para beneficiar sus minerales con el sistema de hervición, sino repasaban todos sus metales en buitrón con un capitán de repaso, dos beneficiadores y 24 repasiris que trabajaban solamente de día. En el beneficio se consumían anualmente entre 2000 y 2500 quintales de sal. Entre 1500 y 2000 quintales fueron traídos desde las salinas de Sabelico y Torcoychi a siete leguas distancia, y el resto procedía de Salinas de Yocalla a 28 leguas de distancia (ver Figura 1) con un precio de cinco y medio a seis reales por quintal.

Pasando ahora a la hacienda de beneficio de Siporo conducido por Pedro Malpartida, encontramos una escala de operaciones que en 1842 sobrepasaba en mucho la empresa Uzín, como también a todas las demás empresas de la Provincia de Porco. Había dos ingenios corrientes de la propiedad del Marqués, cada ingenio con una cabeza de seis almadanetas. Aquí se molían los minerales de calidad brosas, con una producción de 20 cajones semanales. También había dos rastras corrientes, que se utilizaban para moler los metales guías (o chaguas), tanto pacos (óxidos de plata) como negrillos (sulfatos de plata); las rastras podían moler tres a cuatro cajones semanales, cuando la producción de la mina era suficiente. Para otros metales comprados de los cacchas (o buscones) en la cancha mina después de los fines de semana, se mantenían tres trapiches, cada uno con sus hornos de calcinación y sus quimbaletes para pulverizar los metales guías extraídos. Sin embargo, los cacchas no acordaban vender sus metales al empresario cuando no se les ofrecía un precio adecuado, que fue motivo de quejas y represalias por parte de Malpartida, como veremos más adelante. ${ }^{63}$

\footnotetext{
${ }^{63}$ En 1851 Nazario de Uzín, para entonces el Presidente de la Diputación Territorial de Minas de Machacamarca, escribió al Prefecto
} 


\begin{tabular}{|c|c|c|c|c|c|c|c|}
\hline & Minas & Ingenios & Rastras & Trapiches & Quimbaletes & Hornos de Quema & Hornos de fundición \\
\hline Siporo & 6 & 2 & 2 & 3 & 6 & 7 & 1 \\
\hline Bartolo & 3 & 1 & 1 & 3 & 6 & 7 & \\
\hline Totales & 9 & 3 & 3 & 6 & 12 & 14 & 1 \\
\hline
\end{tabular}

Tabla 5. Establecimientos, máquinas y minas reclamadas por Pedro Malpartida en 1842. Fuente: ANB MH PPR t.94 no.35. Estado ... (1842) (f.41v).

Trabajo de extracción

\begin{tabular}{|c|c|c|c|c|c|c|}
\hline EMPRESA & Mina & Barreteros & Apires & Palliris & Operarios & Totales \\
\hline \multirow[t]{4}{*}{ MALPARTIDA } & Angustias & 30 & 25 & 20 & 8 & 83 \\
\hline & Cata & 40 & 30 & 15 & 4 & 89 \\
\hline & San Cristobal & 12 & 8 & 12 & 2 & 34 \\
\hline & Socabón & 12 & 9 & 5 & 3 & 29 \\
\hline Subtotal & 4 & 94 & 72 & 52 & 17 & 235 \\
\hline \multirow[t]{2}{*}{ UZIN } & La Pasión & 44 & 30 & 13 & 6 & 93 \\
\hline & Santiago & 22 & 14 & 15 & 3 & 54 \\
\hline Subtotal & 2 & 66 & 44 & 28 & 9 & 147 \\
\hline TOTAL & 6 & 160 & 116 & 80 & 26 & 482 \\
\hline
\end{tabular}

Trabajo de beneficio

\begin{tabular}{|c|c|c|c|c|c|c|c|c|c|c|}
\hline INGENIO & Morterados & Rastras & Trapiches & Quimbaletes & $\begin{array}{c}\text { Hornos de } \\
\text { quema }\end{array}$ & $\begin{array}{l}\text { Horno de } \\
\text { fundición }\end{array}$ & Buitrones & Fondos & Otros & $\begin{array}{c}\text { Total } \\
\text { trabajadores }\end{array}$ \\
\hline \multicolumn{11}{|c|}{ SIPORO (Malpartida) } \\
\hline$N^{\circ}$ de máquinas & 2 & 2 & 3 & 6 & 7 & 1 & 1 & - & - & \\
\hline $\mathrm{N}^{\circ}$ de trabajadores & 16 & 11 & 3 & 24 & 4 & 1 & $40-50$ & - & 8 & $107-117$ \\
\hline \multicolumn{11}{|c|}{ BARTOLO (Malpartida) } \\
\hline$N^{\circ}$ de máquinas & 1 & 1 & 3 & 6 & 7 & - & 1 & 6 & - & \\
\hline$N^{o}$ de trabajadores & 10 & 6 & 1 & 12 & 4 & - & $20-25$ & 6 & 4 & $63-68$ \\
\hline $\begin{array}{l}\text { Subtotal de } \\
\text { trabajadores }\end{array}$ & 26 & 17 & 4 & 36 & 8 & 1 & $60-75$ & 6 & 12 & $170-185$ \\
\hline \multicolumn{11}{|c|}{ CHARICHARI (Uzín) } \\
\hline$N^{\circ}$ de máquinas & 1 & 1 & nd & nd & 1 & - & 1 & - & - & \\
\hline$N^{o}$ de trabajadores & 10 & 5 & - & - & 2 & - & 27 & - & - & 44 \\
\hline TOTAL & 36 & 22 & 4 & 36 & 10 & 1 & $87-102$ & 6 & 12 & $214-229$ \\
\hline
\end{tabular}

Tabla 6. Trabajadores de Machacamarca en 1843. Empresas de Pedro Malpartida (Siporo y Bartolo) y de la testamentaria de Uzin (Charichari) (por actividad) Fuente: ANB MH PPR t.94 n 35. "El estado en que se halla la industria mineralójica" (1842-3). 
El ingenio del Carmen, propio de Malpartida, en el Cantón de Bartolo (hoy Betanzos), también estaba corriente con una cabeza de cinco almadanetas. Aquí también se molían las brosas, con una producción de 10 cajones semanales. Había una rastra en este ingenio para los metales guías, que molían de tres a cuatro cajones por semana. Y como en Siporo, Malpartida poseía tres trapiches en Bartolo, cada uno con su horno de calcinación y su quimbalete para moler las guías (Tabla 5).

Resumiendo, Malpartida tenía 12 quimbaletes, dos en cada uno de sus seis trapiches, y 14 hornos de calcinación entre los seis trapiches y los tres ingenios. Disponía de un total de 17 almadanetas entre los tres ingenios. También había un horno de fundición para fundir las almadanetas y los quijos; $y$ se refiere a una parada de seis fondos en Bartolo, aunque el principal sistema de beneficio fue por buitrón.

Así, la amalgamación de la plata con azogue se realizaba al estilo tradicional con los pies de los indios que repasaban las harinas en los buitrones correspondientes a cada ingenio: las "brosas pacos", beneficiados "por patio crudo" (es decir, sin quemarlas previamente), solo daban de tres a cinco marcos de plata por cada cajón. Los metales guías también se beneficiaban en buitrón, los pacos en crudo y los negrillos (polvorillas y acerados) después de quemarlos en los hornos de calcinación, produciéndose entre 10 a 25 (raras veces 50) marcos por cajón. ${ }^{64}$

\section{Los trabajadores}

En cuanto a la fuerza de trabajo, Malpartida dijo emplear en las minas más de 500 trabajadores "entre barreteros,

de Potosí sobre un acuerdo que se intentó celebrar en junio del año anterior para que, "hecha la partija de metales entre el patrón i los cacchas, no pudiesen éstos enajenar lo que les hubiese correspondido sin voleta de aquel, para impedir hurtos ...". Pero esto significaba que "cada mina tubiese un almacen especial donde se depositasen los metales hasta su venta, y un administrador muy honrado que corriese con ellos". Frente a esta imposibilidad, "los patrones i los administradores no solo autorisan a los cacchas para que vendan los metales que les ha cabido en la partición a quien les paresca con absoluta libertad, sino que también les permiten conducirlos a sus casas cuando no admitir el precio ofrecido en la cancha por los trapicheros". AHP PD 693 no 19. 31.iii.1851.

${ }^{6}$ Según Nazario de Uzín, en Siporo las brosas producían cuatro marcos/cajón, los pacos 30 marcos/cajón y los negrillos 40 marcos/ cajón. Ver ANB MH PPR t.91 no 35, Estado ... (1842) (f.4or). apires, palliris, directores mineros, herreros, capitanes, arradores, guarda minas y administradores". Ahora bien, este número no es tan diferente de los 482 trabajadores de minas que aparecen en la Tabla 6: las ambiciones de Malpartida le llevaban a pretender a la posesión de todas las minas de Machacamarca como parte del Cantón Siporo, del cual él se consideraba el propietario en sustitución del Marqués ausente. Es posible, entonces, que Malpartida esté incluyendo a los trabajadores de Uzín activos en el Cerro como si fueran sus propios dependientes.

Malpartida, como patrón, también ponía las herramientas, acero, carbón, velas y pólvora, calculándose los gastos semanales de cerro (llamados "semaneras") en aproximadamente 1800 pesos. Estimaba su producción global en aproximadamente 30 cajones de metal por semana ("brosas, llampos y guías"); por lo tanto, el costo por cajón puesto en la cancha mina era de aproximadamente 60 pesos.

La fuerza de trabajo del sector de beneficio se desglosaba por máquina según se percibe en la Tabla 6 . Se trata de un total de entre 214 y 229 empleados en este sector. Juntos con los ca.50o trabajadores del cerro (extracción), podemos estimar la fuerza de trabajo de Malpartida y Uzín en más de 700, o sea, dos veces la fuerza de trabajo de la Sociedad Huanchaca en el mismo año de 1842. Este cálculo coincide con las cifras independientes de Uzín que aparecen en la Tabla 6 , aunque allí las cifras correspondientes a las minas de Uzín se dividen entre las dos empresas, mientras que Malpartida prefiere englobarlas todas dentro de su propia empresa.

\section{Los transportistas}

También había un contingente de transportistas esenciales para el suministro de combustible y sal, y para la baja de los minerales cada semana desde las cancha minas a los ingenios y rastras. A éstos se les pagaban cinco pesos por cada cajón de 200 arrobas de brosas, y a siete pesos por las guías, por ser la distancia tres leguas entre mina e ingenios. Los establecimientos consumían anualmente de 60 a 80.000 cargas de leña, conducidas desde lejos por los leñeros en burros y llamas, que costaban un peso por cada diez cargas de a dos arrobas cada una. Cuando escaseaba, las cargas costaban más, e incluso se les daba de adelantado a los leñeros. Todo se pagaba con dinero al contado. 
Finalmente, se consumían también 3000 quintales de sal mensualmente (36.00o quintales por año), que se traían desde Salinas de Yocalla a 30 leguas de distancia. Se pagaban en dinero al contado, y Malpartida comentó que la sal generalmente escaseaba.

\section{El salario}

El salario de los jornaleros de Machacamarca se construía de una manera compleja, que puede contrastarse con la forma salarial en otros centros mineros. En primer lugar, se pagaba parte en plata efectiva y parte en "habilitos" de ropa y comestibles. Esto también fue el caso en otros centros; la diferencia en el caso de Siporo fue la proporción excepcionalmente alta del salario que fue conmutada a género, y los precios exorbitantes a que se calculaba el valor (y de ahí la menor cantidad) del género recogido por cada trabajador. Los restos, o haberes debidos, se usaban también para pagar los "entierros, fiestas, casamientos, tributos, arriendos, \&ca. \&ca.". Aquí, entonces, a diferencia de Huanchaca, las gabelas estatales y eclesiásticas se pagaban, no por la empresa, sino del mismo salario del trabajador. Además, según Nazario de Uzín, se calculaba el jornal, no en horas o en días "como lo previene la Ordenanza con la espresión de 'Sol a Sol'", sino en mitas "de dos tiros [sc. de pólvora]".

Finalmente, se permitía que los trabajadores hiciesen sus "buscas" como cacchas los días sábado y domingo, cuando entrarían a las minas con las herramientas del patrón para sacar todo el mineral que pudiesen o quisiesen. Este mineral lo dividirían después entre ellos mismos y el patrón, quien les compraba la otra mitad a precios convenidos, resultando a favor de cada trabajador la suma de dos, cuatro - y a veces 30 ó 40 - pesos por semana, "fuera de lo que sacan y venden ocultamente, burlando la vigilancia de los dependientes". Según, Pedro Malpartida, la suma que gastaba en comprarles sus minerales a los cacchas alcanzaría a 2000 pesos semanales. Todos los minerales procedentes del caccheo se beneficiaban en los trapiches.

Tanto Nazario de Uzín como Pedro Malpartida denunciaban la práctica del caccheo como algo que iba en contra de las Ordenanzas y en provecho excesivo de los trabajadores. ${ }^{65}$ Para Uzín, "semejantes ventajas pasan de la esfera de jornal a la de un sueldo"; sin embargo, "nada bastaría para

${ }^{65}$ Ver la nota 63. desaparecer un uso tan arraigado como lucrativo". Pero al mismo tiempo denuncia el "poder sultánico" de Malpartida, no sólo por su antagonismo contra él mismo, sino porque se cree "árbitro y común Señor de los hombres y de los edificios que éstos trabajan para su morada en Machacamarca, únicamente porque el Suelo está comprendido en las pertenencias del fundo arrendado". Varias veces Malpartida había arrojado a los trabajadores de sus casas, haciendo valer impunemente su derecho señorial (como arrendatario del Marqués de Cáceres) sobre el derecho de compra o de edificación de los trabajadores. Para Uzín, estas acciones de Malpartida iban en contra de "nuestro sistema fundamental" [sc. de propiedad privada liberal]; y pidió al Gobierno que se nombrase "una autoridad especial para solo este Mineral", ya que los Juzgados de Letras y de Paz no parecían capaces de hacerse respetar por Malpartida.

De hecho, la situación laboral en Machacamarca parece haber llegado a un grado de tirantez mayor que lo que hemos encontrado en otros centros mineros. En primer lugar, la institucionalización del caccheo fue un aliciente excepcional que atraía a los trabajadores al mineral, y que no se ofrecía ni en Portugalete (Chichas) ni en Pulacayo (Huanchaca). En una situación donde cada centro competía con los demás para atraer a mano de obra escasa, era imposible abolir una costumbre que aseguraba el suministro de trabajadores. Por otra parte, la práctica del caccheo - y sobretodo los hurtos clandestinos - restringieron las posibilidades de acumulación de la empresa, provocando la cólera casi endémica del patrón contra lo que él llamaba "el absoluto vicio e inmoralidad de los trabajadores".

\section{"Estafar para no estafarse": la justicia de los azo- gueros}

Podemos examinar más de cerca la relación patrón-trabajador en Siporo, y su expresión mediante la forma del salario, a través de las diligencias practicadas en 1835 por el minero potosino de origen arequipeño, Pedro Laureano Quesada. En aquel entonces Quesada fue juez comisionado por el Tribunal General de Minería para investigar el tratamiento de los trabajadores por Pedro Malpartida en los asientos de Siporo, Piquiza y Machacamarca. ${ }^{66}$ En

\footnotetext{
${ }^{66}$ ANB MH TGM t.47 n ${ }^{\circ} 7$ (1836). Testimonio de las diligencias practicadas por el Juez Comisionado en los acientos de Siporo, Piquiza y Machacamarca sobre el manejo del C. Pedro Malpartida con los jornaleros trabajadores. Año 1835 .
} 
este expediente se anticipan varios de los puntos mencionados después por Uzín, y se escuchan las voces de diversos testigos llamados a deponer contra Malpartida. Sin embargo, es palpable el miedo que pesaba sobre los testigos con respecto a posibles represalias posteriores por parte del patrón.

El problema empezó en febrero de 1835, cuando el Curaca de Siporo, don Blas Barea, cuyos tributarios quechuahablantes trabajaban en la hacienda y las minas de Malpartida, se encontró incapaz de entregar más de 20 pesos de tributo de los 47 que le correspondían, porque sus tributarios fueron obligados a recibir sus jornales en género en lugar de dinero. Un indígena había ido a la Hacienda de Siporo para conseguir el dinero que necesitaba para pagar su tributo, y encontró - después de trabajar "una porción de días encerrado" - que su única retribución fue un pañuelo del valor de un real, y una vara de bayeta cuyo valor fue calculado con un precio muy elevado.

Entonces el sucesor de Leandro de Uzín como Gobernador de la Provincia de Porco, Ciudadano Nicolás Dorado, como responsable ante la Prefectura para el entero del tributo de su Provincia, envió un mensaje indignado al Corregidor de Siporo, preguntando por qué no había ayudado al Curaca a resistir los abusos. Según el Gobernador, todos los jornales debían ser en dinero efectivo, salvo si los trabajadores pedían especies, cuando deberían darse en "precios regulares". Además, los trabajadores tenían la libertad de elegir dónde querían trabajar; y el Corregidor y el Juez de Paz debían velar contra los abusos.

Su mensaje fue publicado por bando en Siporo el 9 de marzo de 1835, copias fueron fijadas en los lugares públicos, y el Corregidor fue ordenado a explicar "su tenor a los Curacas y demás indígenas". Entonces Blas Barea, envalentonado, amenazó con llevar a todos sus tributarios a trabajar en la mina de La Pasión perteneciente a la Testamentaria de Uzín, donde los pagos se realizaban en dinero efectivo. Aparentemente, la amenaza surtió efecto, y Malpartida respondió pagando los jornales por esa vez en dinero, aunque seguía persiguiendo al Curaca recalcitrante.

Mientras tanto, la carta enviada por Dorado con copia a la Prefectura había llegado al Presidente Andrés Santa
Cruz, quien a través del Ministro de Hacienda José María de Lara ordenó al Tribunal General de Minería de Potosí que enviase inmediatamente a un juez comisionado para investigar a fondo los abusos practicados por Malpartida. Con impaciencia Santa Cruz preguntó: “ise creyó que la autoridad debía reprimir solo los hurtos de los operarios, su insubordinación y falta de respeto, y no los ecsesos de los patrones?" Se nota la exasperación de Santa Cruz con respecto a las actitudes empedernidas de los azogueros de Potosí.

Pedro Laureano Quesada, el Segundo Diputado para aquél año, partió con su comisión para Machacamarca, y el 21 de abril ordenó a Malpartida que se ausentara del pueblo por dos días, para no perjudicar con su presencia el curso de la investigación. Malpartida protestó pero fue convencido. Mientras tanto se invitaba por bando y carteles a todos los trabajadores de Malpartida que compareciesen a presentar sus agravios contra el patrón.

Nadie se atrevió a presentarse. Todos tenían miedo de las represalias que Malpartida tomaría después. En un momento durante la espera, un "anciano imparcial, y digno de crédito" se acercó y pronunció:

"Usted no se canse, porque nada ha de adelantar; los comisionados vienen y prontamente se retiran; y en este caso el señor Malpartida a todos los declarantes a punto de palos les encierra en la mina de Angustias ..."

Otro "imparcial y también digno de fé" opinó:

"que eran inútiles los medios indagatorios en el particular, en tanto fuese conductor de Siporo don Pedro Malpartida.' Y queriendo el informante [sc. Quesada] que esto constase de declaración, con lágrimas en los ojos me suplicaron, no les causase tanto mal".

Pero Quesada tenía que cumplir con su comisión. Por oficio escrito llamó a deponer al Ciudadano Basilio Saravia, natural de Poopó con 60 años y ahora residente en Machacamarca. Se trata de un hombre mayor con independencia de criterio con respecto a Malpartida. Este señor dijo que a veces Malpartida les había dado vales a los trabajadores que no querían recibir sus jornales en especies, y que estos vales después se venderían en el pueblo a la mitad de su valor para que el comprador se entendiese 
con Malpartida sobre el cobro total. Citó el caso del trabajador Mariano Subieta quien había planteado el negocio con el mismo deponente, cuando éste fue Juez del pueblo: varios trabajadores se habían acercado para que les midiese las varas de bayeta que habían sacado como avío, y éstas varas habían tenido una octava menos que las varas de ley. ${ }^{67}$

Además, Malpartida era prepotente con las autoridades, habiendo pegado al deponente en 1833 cuando estuvo de Juez, llenándole de contusiones, porque no había querido levantar un sumario contra cuatro trabajadores de la mina rival de La Pasión. Uno de los cuatro había maltratado "levemente" a una mujer de la hacienda de Malpartida; y si Malpartida fue un verdugo con su propia gente desleal, no por eso dejaría de defender a su gente contra los trabajadores de la empresa rival. Entonces, se hizo un sumario que no condujo a nada, y Malpartida se apropió del expediente. Según Saravia, Malpartida había pegado también a los Jueces de Paz de Siporo, Manuel Pinto y Narciso Delgadillo, y al Corregidor de Siporo, Tomás Prudencio.

Finalmente, cuando Ildefonso de Vargas y Flor vino al pueblo comisionado por el Tribunal General de Minería, y publicó un bando invitando a la gente que fabricasen sus casas donde quisieran como su propiedad personal, Malpartida inmediatamente había sacado otro bando con las firmas falsificadas del Juez de Letras y del escribano Valda, sujetando tal derecho de propiedad a su consentimiento previo, como "conductor" de Siporo. Después escondió el bando.

Una vez que había declarado Saravia, Quesada procedió a llamar a todos los individuos mencionados en su testimonio para que hablasen sobre los sucesos alegados:

- Primero, llamó a José de Arrien, natural de los Reinos de España de 36 años y Administrador de los intereses minerales de la Testamentaria de Uzín. Este señor había pedido en vano a Malpartida y al Corregidor

\footnotetext{
${ }^{67}$ Según Saravia, Malpartida daba a los trabajadores la bayeta de sedillo a 12 reales / vara, y la bayeta de chorrillo a seis reales / vara. Id. f.7r. Compárese con el precio de cuatro reales por vara de bayeta de chorrillo alegado por el Administrador de Malpartida (ver más abajo).
}

de Siporo una copia del bando falsificado. Después consultó con el Juez de Letras, quien reconoció la falsificación.

- También se recibió el testimonio de José María Laguna, a quien el Corregidor de Siporo Narciso Delgadillo había ordenado a leer publicamente el supuesto auto del Juez de Letras. El Juez de Letras llegó y le preguntó a Laguna si había visto su firma y la del escribano Valda; Laguna contestó que sí, pero sin poder asegurar si eran verdaderamente sus firmas.

- Tomás Prudencio, por su parte, dijo ser natural de Siporo y minero residente en Colavi la Alta, de 26 años de edad. Afirmó que cuando fue Juez Pedáneo de Siporo en $1826,{ }^{68}$ Malpartida quiso encerrar en la mina Angustias a un hombre quien había robado una vaca del sobrino de Malpartida; y cuando Prudencio se opuso a tal procedimiento, Malpartida le propinó "tres trompadas". No pudo contar con el apoyo de Leandro de Uzín, Gobernador del Partido de Porco, porque en ese momento Uzín fue socio y "protector de Malpartida".

- Mariano Subieta, barretero de Malpartida con 49 años y nativo de Potosí, también fue llamado a comentar la narrativa de Saravia. Refiriéndose al vale de 40 pesos que había querido vender a Saravia en 20 pesos, agregó que cuando éste rechazó su propuesta, había llevado el vale a su patrón Malpartida, quien le había dado solo cuatro pesos en efectivo y el resto en género.

- Después compareció Blas Barea, barretero de 26 años en la hacienda de La Pasión perteneciente a la Testamentaria de Uzín; Barea había precipitado la investigación, y se animó por el bando de Dorado a amenazar con sacar a sus contribuyentes de la hacienda de Malpartida para que trabajasen en la hacienda de Uzín, con que Malpartida aceptó pagar los jornales pendientes en dinero.

- Luego, se llamó al Administrador de cerro y minas de Malpartida, el Ciudadano Juan Feraudi de 58 años de edad, a quien se preguntó por el valor que resultaba después de amasar una fanega de harina de trigo para el pan repartido como avío a los trabajadores. Feraudi dijo prudentemente que no sabía, porque recibió el pan ya amasado de Siporo. Después se le preguntó por el precio de todas las especies repartidas en lugar

\footnotetext{
${ }^{68}$ La fecha puede estar equivocada: según su propio testimonio, Prudencio en ese momento hubiera tenido sólo 17 años. Quizás el escribano ha confundido el año de referencia con la edad del testigo.
} 
de dinero a los trabajadores. Contestó que la carga de maíz valía cuatro pesos, la de chuño también, el cesto de coca 20 pesos, la vara de cordellate cuatro reales, la vara de bayeta chorrillo lo mismo, y la vara de bayeta blanca tres reales. El valor del quintal de charque no sabía, porque llegó de Siporo ya atado en porciones de a medio real. La carga de harina de moco se daba en cuatro pesos.

Dado que ningún individuo de Machacamarca se presentó voluntariamente a deponer contra Malpartida, el Juez Comisionado decidió trasladarse a Piquiza y Siporo para seguir la investigación. En Piquiza tampoco hubo un solo individuo dispuesto a quejarse contra Malpartida. En Siporo, Quesada mandó primero que compareciese Manuel Pinto, el Juez de Paz, quien se acordó de una "reyerta" que había tenido con Malpartida en 1823 durante un partido de pelota, cuando jugaron en bandos opuestos con otros cuatro individuos. Malpartida le había dejado con algunas contusiones en la cara, a pesar de que en aquel entonces ejercía el cargo de Juez. Por su parte, Narciso Delgadillo dijo haber recibido "dos empellones" cuando trabajaba para Malpartida en 1825, y otro después, aunque no ejercía el cargo de Juez.

Entonces Quesada pasó al ingenio de Malpartida y, llamando a todos los indios repasiris, les mostró el pan encontrado en la tienda pulpería del mismo ingenio, que parecía "regular en su calidad", y les preguntó "en su idioma" si era el mismo que en ese momento les daba de avío, y cómo se comparaba con el pan recibido en ocasiones anteriores. Todos contestaron que era el mismo, pero que en el pasado hubo variaciones en el tamaño. Entonces se llamó al panadero, Nicolás Luna, quien dijo que se sacaba a ocho pesos la fanega de harina de trigo que amasaba. Este testimonio fue confirmado por el Administrador General de Malpartida, Fernando Morales, quien, sin embargo, no llevaba ningún libro con los detalles. Sólo hubo un cuaderno mostrado por el mismo Pedro Malpartida, donde se pudo leer que en 1832 la fanega de harina valía seis pesos, pero convertido en pan producía nueve pesos cuatro reales.

Así se terminó la investigación. Pedro Laureano Quesada se exculpó de los defectos que pudo tener la información recogida, refiriéndose a las advertencias de los dos ancianos a principios de su comisión, y a la reticencia de la gente que no había querido deponer contra Malpartida. Lo que a él le causaba más escándalo fue el precio y el peso del pan repartido, pero la investigación fue incompleta por las razones anticipadas por los dos ancianos.

Sin embargo, el Juez Comisionado Quesada no se quedó con la información recogida, por parcial que fuese, sino ofreció además su propia evaluación de la situación. Y aquí viene lo más llamativo del expediente. Quesada empezó dando rienda suelta a todos los prejuicios de los azogueros potosinos contra la gente trabajadora. Se refirió al "carácter y perversas abitudes de los trabajadores", y a la "forzosa presición que tienen los infelices azogueros de balerse de jente tan prostituida". Para Quesada, fue "de Justicia indicar obre en parte la prudencia lo que autorisa la necesidad (entendiéndose escluida de esta reflexión el ecseso de las utilidades del pan que dicen practica Pedro Malpartida)". Esta frase nos devuelve a la esencia de la relación tirante entre el azoguero y los trabajadores en la hacienda de Siporo. Pues, si los trabajadores se dedicaban al robo en las minas, el azoguro estaba justificado - por la "prudencia" y la "necesidad" - en "un disímulo racional en su comportación":

"Si los trabajadores absteniéndose del hurto cumpliesen religiosamente, llenando como es devido las horas de su jornal, sería un criminal el azoguero que los estafase su justo haber. Mas como esta jente abandonada solo cuida del robo en toda linea, se ve el azoguero sacrificado, y la utilidad que persive en las havilitaciones con mucho no es un compensativo a los grandes perjuicios $\mathrm{cu}$ yos autores son ellos mismos. Hurto de tiempo: hurto de metales: $y$ una continuada privación que sufre el azoguero de los placeres de la sociedad, demandan imperiosamente un disimulo racional en su comportación. Y es con lo que el comicionado termina su informe. Dios guarde a Vuestra Gracia. Pedro Laureano Quesada. Sala de Acuerdos. Potosí, 29.1 iv.1835 [énfasis del autor]".

La lógica de Malpartida y de Quesada es la misma: si los trabajadores nos estafan a nosotros, no hay alternativa sino estafarles también a ellos. Las pérdidas del azoguero en el caccheo se compensan con las utilidades injustas en las "havilitaciones". El acuerdo entre "socios", que justificó el caccheo en los trabajos "sin método", fue desconocido en el sistema "reglamentado" por los empresarios mineros, quienes intentaban compensar los valores "hurtados" mediante estafas a los trabajadores. Así las relaciones entre el patrón y los trabajadores llegaron a la total desconfianza. Con razón Santa Cruz expresó sus 
dudas sobre la capacidad del Tribunal General de Minería de administrar la justicia equitativamente.

¿Cómo entender el comportamiento de Malpartida y el apoyo que finalmente recibió del Juez Comisionado Quesada? En primer lugar, debe notarse que Quesada no expresó ninguna crítica de la violencia de Malpartida contra las autoridades nacionales, los Jueces de Paz y de Letras, quienes deberían haber intervenido para resolver los conflictos entre el patrón y sus trabajadores. Se trata de la misma actitud que ya vimos en el caso de Huanchaca: para los azogueros, la tarea de velar por el buen comportamiento de los trabajadores no fue algo que debía entregarse al poder público. Fueron los mismos azogueros los que deberían castigar y premiar a su propia gente, elijiendo los métodos que les parecían los más adecuados. Su comportamiento era un atributo de su libertad como capitalistas guiados por su propia percepción del interés económico de todos, que por sí solo garantizaría los mejores resultados para todos. Las autoridades estatales en esto no tenían ningún papel que cumplir.

Pero en el caso de Malpartida la situación fue ambigua, porque no sólo fue un patrón "ultra-liberal", sino además se consideraba acreedor de los derechos "feudales" en cuanto arrendatario del fundo del Marqués de Cáceres. ${ }^{69}$ La base de su empresa estaba en los privilegios y la propiedad del terrateniente Peralta, ausente en España; y los derechos de los trabajadores, planteados por Santa Cruz, no cabían dentro de esta visión "sultánica" de las cosas. Se produjo, entonces, una convergencia paradójica entre la libertad absoluta del minero capitalista de disponer "racionalmente" de todos los factores de producción, incluso la fuerza de trabajo, y el absolutismo "feudal" de la nobleza española contra los cuales se dijo haberse realizado la revolución. La paradoja era que, en su formulación extrema (y a diferencia de Huanchaca), la "libertad" del azoguero dificilmente pudo distinguirse de la "tiranía" denunciada por los patriotas liberales.

Pedro Laureano Quesada fue también un crítico acérrimo del Código Mineral Santa Cruz, publicado el 24 de febrero del mismo año. ${ }^{70}$ Las críticas de Quesada al Código, publicadas el 2 de abril, llegaron a 58 páginas

\footnotetext{
${ }^{69}$ Ver Crespo Rodas et.al., op.cit., p.106, n.2.

${ }^{70}$ Código Mineral Santa Cruz, Imprenta Chuquisaqueña administrada por Manuel Venancio de Castillo. Sucre 1835 [BNB M 422 III].
}

contemptuosas $^{71}$ dirigidas a defender la libertad total del azoguero frente a la "mania reglamentaria" del gobierno. Fueron seguidas por una solicitud formal de suspensión del Código, propuesta por la Junta General de Azogueros reunidas en Potosí, y fechada el 14 de julio de 1835. De hecho, el juicio fracasado contra Malpartida sucedió paralelamente con la discusión sobre el Código. En este contexto Malpartida no pudo sino aparecer a los demás azogueros como defensor de su libertad frente a lo que todos consideraban el intervencionismo arbitrario del gobierno crucista. Estas consideraciones explican los comentarios de Quesada al final del expediente, donde desconocía las advertencias ofrecidas por los dos sabios "ancianos" al principio de su misión.

\section{* La minería de la provincia de Porco en 1850}

Veamos finalmente una Tabla conspectual de la minería en Porco, compilada en 1850 bajo el gobierno del Presidente Belzú (Tabla 7), que nos ofrece una visión comparativa de las empresas de la Provincia a mediados del siglo XIX.

En términos de producción semanal, Carguaycollo ya estaba en la delantera con 300 marcos semanales, Siporo-Machacamarca venía después con 250 marcos, seguido por Tolapampa (Huanchaca) con 180 marcos. Sin embargo, el número de trabajadores era a la inversa: en Tolapampa hubo 1000, en Siporo-Machacamarca 671, y en Carguaycollo 212. La explicación yace, en parte, en la gran diferencia entre las leyes de los metales explotados: Carguaycollo producía sólo 5 cajones de 50 quintales por semana, pero tenía acceso a abundantes guías con una ley de 100 marcos por cajón. Siporo-Machacamarca producía 50 cajones de 50 quintales por semana, pero tenía acceso a guías mucho menos valiosas que las de Carguaycollo con solo 25 marcos por cajón, además de brosas de sólo cinco marcos por cajón. Finalmente, Huanchaca en Tolapampa producía sólo diez cajones de 50 quintales por semana, y la ley estaba relativamente baja a sólo 18 marcos por cajón. Debemos suponer que muchos de sus 1000 trabajadores estaban empleados en las grandes

\footnotetext{
${ }^{71}$ Pedro Laureano Quesada, Observaciones al Código de Minería, publicado en 2 de abril de 1835 ... [BNB M422.IV], seguido por Junta General de Azogueros, Piden la suspensión del Código Mineral ... [BNB $\mathrm{Bb} 330]$.
} 


\begin{tabular}{|c|c|c|c|c|c|c|c|c|c|c|c|c|}
\hline 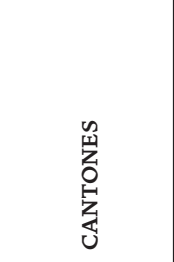 & $\underset{\Sigma}{\sharp}$ & 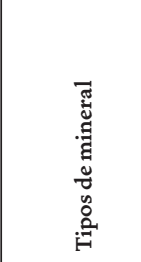 & 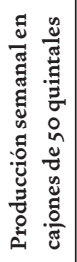 & & 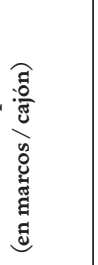 & 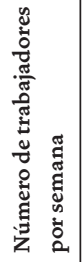 & 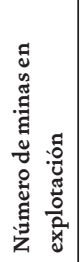 & 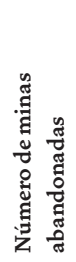 & & 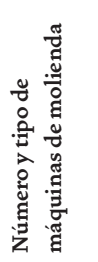 & & 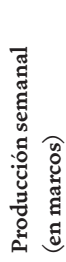 \\
\hline \begin{tabular}{|l|} 
Siporo \\
Machacamarca
\end{tabular} & $\begin{array}{l}\text { Angustias y } \\
\text { Barcelona } \\
\text { El Restaurador } \\
\text { El Ymbasor } \\
\text { S. Gregorio } \\
\text { Guadalupe } \\
\text { La Pación } \\
\text { San Matías }\end{array}$ & $\begin{array}{l}\text { Pacos } \\
\text { Acerados } \\
\text { Polvorilla } \\
\text { Paco mulatos } \\
\text { Soroches } \\
\text { Agüijerados } \\
\text { Chumbes }\end{array}$ & 50 & $\begin{array}{c}\text { Guías } \\
25\end{array}$ & $\begin{array}{c}\text { Brosas } \\
\\
5\end{array}$ & 671 & 8 & 124 & Morterados & $\begin{array}{c}\text { Rastras } \\
3\end{array}$ & $\begin{array}{c}\text { Trapiches } \\
6\end{array}$ & 250 \\
\hline $\begin{array}{l}\text { Bartolo } \\
\text { Tacobamba }\end{array}$ & & & & & & & & & $\begin{array}{l}3 \\
2\end{array}$ & & & \\
\hline Tomave & $\begin{array}{l}\text { Almadaneta } \\
\text { Rosario } \\
\text { Chuquiribi } \\
\text { Palmero }\end{array}$ & $\begin{array}{l}\text { Chumbes } \\
\text { Acerados } \\
\text { Paco } \\
\text { Acerados }\end{array}$ & 2 & & 40 & 320 & 4 & 30 & 3 & 3 & & 80 \\
\hline Tolapampa & \begin{tabular}{|l} 
Esperanza \\
Tajo \\
San León \\
Santo Tomás
\end{tabular} & $\begin{array}{l}\text { Mulatos } \\
\text { Negrillos } \\
\text { Negrillos } \\
\text { Negrillos }\end{array}$ & 10 & & 18 & 1000 & 4 & 20 & & 1 & 5 & 180 \\
\hline $\begin{array}{l}\text { Coroma y } \\
\text { Carguaycollo }\end{array}$ & $\begin{array}{l}\text { San José } \\
\text { Candelaria } \\
\text { Dolores } \\
\text { Santa Barbara } \\
\text { Lumbrera } \\
\text { Tacana chica } \\
\text { Barreno } \\
\text { Viscachani } \\
\text { Rosario } \\
\text { Catita } \\
\text { San Miguel } \\
\text { San Pedro Muñoz }\end{array}$ & $\begin{array}{l}\text { Acerados } \\
\text { Acerados } \\
\text { Chiniliga } \\
\text { Acerados } \\
\text { Chiniliga } \\
\text { Chiniliga } \\
\text { Acerados } \\
\text { Chiniliga } \\
\text { Chiniliga } \\
\text { Chiniliga } \\
\text { Chiniliga } \\
\text { Chiniliga }\end{array}$ & 5 & 100 & 30 & 212 & 12 & 5 & & 1 & 5 & 300 \\
\hline Caiza & $\begin{array}{l}\text { Socavón S. Pedro } \\
\text { San Rafael } \\
\text { San José de } \\
\text { Machuca }\end{array}$ & $\begin{array}{l}\text { Negrillos } \\
\text { Soroches } \\
\text { Soroches }\end{array}$ & 3 & 15 & 30 & 200 & 3 & 25 & 2 & & & 60 \\
\hline Porco & Minas de Caccheo & Soroches & & 100 & & 50 & 8 & 500 & 1 & 1 & & 100 \\
\hline TOTALES & & & 70 & & & 2453 & 39 & 704 & 14 & 12 & 13 & 970 \\
\hline
\end{tabular}

Tabla 7. Estado de la minería en la provincia de Porco, 1850. Fuente: ANB MI PPR t.136 nº 45 (1850). Estado que manifiestan las minas.

obras infraestructurales que echarían la base para el florecimiento de Huanchaca más tarde en el siglo.

Un asiento minero no mencionado hasta ahora aparece en cuarto lugar en la Tabla 7. Se trata del antiguo cerro y mineral del mismo asiento de Porco, con ocho minas en explotación (y 500 abandonadas) que eran "minas de caccheo" trabajadas por 50 cacchas, y que producían 100 marcos semanales con minerales guías de ley de 100 marcos por cajón. O sea, cada caccha producía en promedio un quintal por semana de harina mineral de muy alta ley. Ya vimos que el Coronel Manuel Antonio Tardío buscaba fondos para fomentar la minería en el asiento de Porco, después de vender Huanchaca a Mariano Ramírez y sus 
socios en 1833 . En 1842 se mencionan las máquinas de moler en Porco (un trapiche y una rastra), cuyo uso seguramente fue compartido por los cacchas. No se menciona el tipo de beneficio, pero más tarde en el siglo XIX se usaban huayras - fundiciones de viento portátiles, descendientes de modelos pre-hispánicos - (Peele 1893, Lechtman 1976, Van Buren 2005), apropiados para el beneficio de minerales de alta ley. El uso de la fundición de viento habrá sido apropiado por la riqueza de los minerales, dando a Porco y sus cacchas un perfil único entre los centros mineros de la Provincia. ${ }^{72}$

\section{* Conclusión}

Hemos revisado varios tipos y escalas de organización minera en Potosí a principios de la República a partir de una fuente excepcional, el "Estado" de 1842-43. Después de considerar el notorio rescate de plata entre Lípez y Salta, hemos restaurado la importancia paralela del rescate Lípez-Potosí, descrito en 1852 por el "Aldeano" de San Pablo, Carlos Quiróz. El complejo fomento-rescate entre los pequeños mineros, cuya producción podía fluir tanto hacia el Banco de Rescates como a la "ruta de las pastas", estaba en la base del arranque minero de Carguaycollo a mediados del siglo, cuando se recurría a medios internos de capitalización sin la necesidad de recurrir a capitales extranjeros.

También detectamos una capa indígena de cateadores, cuyos hallazgos se capitalizaban mediante el fomento criollo antes de venderse al fomentador, y después por éste a un especulador mayor. En este período fracasaron los intentos de reflotar la Mesa de Plata de San Antonio de Lípez; pero en Carguaycollo y Tomave se formaban asociaciones entre cacchas y fomentadores que ahorraban los jornales inherentes a un sistema "arreglado". Según Carlos Quiróz, el caccheo estaba en la base de la boya de Carguaycollo en 1850, y también prometía gran prosperidad para Lípez. Esta dinámica fue un elemento importante en el proyecto político-económico de Manuel Isidoro Belzú, que sin embargo se debilitaba por el escape clandestino de pastas de plata hacia Argentina

72 Mary Van Buren, durante su trabajo etnoarqueológico en Porco en 2001-2, pudo trabajar con quizás el último beneficiador con huayra, don Carlos Cuiza (2005). y Chile desde 1845. Queda la pregunta si se podría haber tapado este hueco con mayores fomentos y rescates bolivianos, como sugería Carlos Quiróz, junto con mejores patrullas en las fronteras, como las que fueron desplegadas antes de la Ley de Libre Extracción de Pastas de 1872 .

Hemos insistido en la necesidad de identificar los medios tecnológicos en uso en cada centro minero, tanto en la extracción como en el proceso de beneficio. Por ejemplo, la presencia de negrillos (sulfatos de plata) de buena ley exigía la construcción de hornos de quema de las harinas minerales, molidas normalmente en rastras y morterados mecánicos (los quimbaletes manuales se guardaban sobretodo para la plata de muy alta ley, como las guías y chaguas, y para el oro). Hemos notado la presencia de paradas de fondos en Tomave en manos de un pequeño minero-aviador, que pueden haber servido las necesidades de los cacchas y otros mineros sin medios de beneficio propios. El método de hervición de Alonso Barba permitía ahorrar salarios, además de ser mucho más rápido que el sistema tradicional de patio (el proceso tardaba " 24 horas", contra seis-siete semanas en buitrón). Al mismo tiempo la fabricación y reparación de los fondos de cobre exigía la construcción de fundiciones de cobre, con materia prima de Corocoro (La Paz). Hubo quejas contra el precio del cobre, pero más se protestaba contra el precio del azogue hasta la llegada en 1850 del azogue de California.

Aquí es de notar la ausencia del sistema centro-europeo de beneficio en barriles giratorios, introducidos en vano por Nordenflicht y sus colegas en Potosí en los 1790s, y nuevamente en un experimento fracasado en 1823.73 Este método fue introducido con éxito en México en los 1820s, y también estaba presente en el Perú republicano. En Bolivia, en cambio, los azogueros de las provincias no se dejaban convencer, preferiendo una versión modernizada de los fondos de cobre de Alonso Barba (Platt 1998-99). El método chileno del escocés Stevenson sólo se introducía en los ingenios de Calixto Yañez (Chichas)

73 En 1843 un beneficiador anónimo de Oruro, “J.D.M.H.", firmó un artículo de periódico sobre los toneles giratorios de Halsbrücke (Alemania). Dijo haber experimentado con los toneles en Bolivia en 1823, un ensayo que terminó, aparentemente, cuando los toneles se reventaron. Ver El Restaurador (Sucre) V.83, 8.viii.1843. Correspondencia. 
y Tudó (Rivera de Potosí), aunque fue proyectado por Mariano Ramírez en Huanchaca.

Con respecto al debate sobre el pago a veces "abusivo" a los trabajadores de una parte de su salario en género, nuestros datos sugieren una situación compleja: todo dependía del valor atribuido al género al momento de pagar los salarios. Si los valores eran bajos, les podría convenir a los trabajadores recibir una parte de su salario en género, sea para su propio uso y el de su familia, sea para revender en el mercado; $y$ a veces lo pedían como parte de su remuneración. Tal fue la situación en Huanchaca. En esta época se trataba de bayetas de lana fabricadas en Oruro, más que de telas importadas. En cambio, si el valor del género se computaba a un precio alto, la proporción del salario pagado en género ya no le convenía al trabajador, y resultaban situaciones conflictivas como en Siporo. Aquí el intento de Malpartida de pagar a los indios tributarios con género costoso en lugar de dinero conducía a la amenaza por parte del Curaca Barea de una "huelga" mediante la transferencia de sus indios al ingenio de Nazario de Uzín, con lo cual pudo frenar las intenciones del déspota de Siporo. La capacidad de los indios tributarios de imponer "huelgas" contra empresas abusivas también la hemos notado en el caso del Curaca de San Pablo de Lípez en 1859, y es llamativo que estas huelgas de campesinos-mineros fueron impulsadas, en cierta medida, por la presión tributaria contra la mesquindad patronal.

Hemos enfatizado nuevamente la imbricación estrecha entre la economía minera y los calendarios tributarios de los indios (véase Platt 1987). Se producía una integración entre las actividades agropastoriles y la búsqueda de dinero tributario, por una parte, con la demanda minera de transporte y de energía humana, por la otra, constituyéndose en algunos casos en lo que puede denominarse un tipo de "mita informal", donde fue la presión tributaria la que forzaba la participación indígena en el trabajo minero, en lugar de los "entables" con los azogueros como a fines del siglo XVIII (cf. Tandeter 1992). A diferencia de un mercado "libre" de trabajo, el acuerdo entre el empresario y el Curaca recaudador se negociaba en función de las necesidades puntuales de ambos. En Huanchaca se hacían contratos con los Curacas de la provincia de Chichas para asegurar la presencia en Porco de tributarios indígenas chicheños para trabajar en el morterado y el cedaseo, dos actividades peligrosas. En algunos casos se pagaba el tributo individualmente, en otros se emitían vales directamente al Curaca para la suma tributaria entera, que eran negociables en Potosí. En Huanchaca incluso se premiaba la venida de los tributarios desde lejos.

Por otra parte, la política laboral de Pedro Malpartida en Siporo - "estafar" con el precio de los géneros para compensar la supuesta "estafa" del caccheo - reflejaba una actitud muy difundida entre los azogueros potosinos, que contaba con el apoyo de los diputados del mismo Tribunal General de Minería como parte de su campaña contra las políticas laborales de Santa Cruz. Estos señores defendían un sistema ultra-liberal del capitalismo que confluía, en el caso de Malpartida, con el "despotismo feudal" atribuido a los españoles. Provocaron así el abandono del nuevo Código de Minería Santa Cruz y la abolición del Tribunal General de Minería solo siete años después de su fundación en 1829 por el mismo Santa Cruz.

En este contexto, el contrapunteo entre los casos de Pedro Malpartida en Siporo y Mariano Ramírez en Huanchaca revela un contraste significativo de procedimientos y sensibilidades; sin embargo, ambos defendían la libertad del empresario de tratar a sus trabajadores como mejor le parecía. En esta actitud subyacen las tensiones, los excesos y, a veces, las formas de corrupción con respecto a los poderes públicos que persistirían y desembocarían, años después, en el Estado minero de los patriarcas de la plata, de las empresas estañíferas de Uncía y Llallagua a principios del siglo XX, de la Asociación de Industriales Mineros de Bolivia fundada en 1924, y de la misma Rosca boliviana. La batalla sigue hoy en la nueva fase del extractivismo, cuando el asalto ahora es llevado a las propias tierras de los campesinos. Al mismo tiempo, el Código Minero Santa Cruz representaba, ya en 1835, los principios en Bolivia de una legislación laboral a favor de los trabajadores y en contra de los excesos de los empresarios, poniendo en un código escrito sus derechos y obligaciones, que puede haber impulsado en 1855 el primer código y reglamentación puesta por escrita por un empresario minero, José Avelino Aramayo en Carguaycollo.

Finalmente, el intento de prescindir de capitales extranjeros era factible, e incluso exitoso, en este primer período de la República, permitiendo un modelo de explotación 
más acorde con las posibilidades del país en base a la producción de monedas de plata y un sistema monetario paralelo (Platt 1986). El fraccionario, o "feble", facilitaba las pequeñas transacciones como medio de cambio en el mercado interno y andino, mientras que las necesidades de importación (sobretodo del azogue) exigían la exportación de "pesos fuertes" (que gozaban de un premio de $11 \%$ sobre su valor nominal en Valparaíso y Londres). Incluso durante el proteccionismo de Belzú era posible transformar "febles" que circulaban internamente en "fuertes" para la exportación a través de letras giradas sobre las casas extranjeras, con una depreciación muy pequeña en el valor nominal de los "febles" (Platt 1986, Mitre 1986). Pero a partir de 1845 el contrabando de plata no-acuñada por la "ruta de las pastas" se ensanchaba, y con los años se volvió incontenible.

A pesar de la liberalización formal de la economía en 1872 con la Ley de Libre Extracción de Pastas, los trabajadores de las empresas ya "reglamentadas" seguían extrayendo una parte de su salario en la forma de metal, a pesar del griterío de los empresarios. En septiembre de 1885, incluso tenemos un atisbo de las prácticas religiosas que expresaban y legitimaban este nuevo tipo de "caccheo liberal" en la vecina Provincia de Chayanta (donde se llamaba juqueo, "robo de buhos"). Según un periodista anónimo de Potosí:

"El 29 [de septiembre] tuvo lugar la fiesta de San Miguel de Aullagas. Es el santo confidente y protector de los ladrones de metales, según la creencia del vulgo: sus bucheadores ${ }^{74}$ devotos concurren al templo llevando cada uno el más rico trozo del metal fino para acomodarlo en el cuerpo y bajo las vestiduras del santo, como ellos acostumbran hacerlo para robar metales de una mina. Esta operación se llama armarse, y el que tiene metales ocultos en el cuerpo está armado, de manera que San Miguel queda armado. Después viene el alferés y rejistra el santo con la misma prolijidad que un chagüiri para desarmarlo o despojarlo de los robos, lo que se llama la chagua ${ }^{75}$. El sacristán tiene derecho a la

74 Bucheadores = "los que llenan la panza" con ricos metales. En ésta y la próxima nota, debe notarse la asimilación del metal recogido a "comida".

75 Del Que. chaway = "esprimir, ordeñar". Los chawiris son los funcionarios de la empresa que "ordeñan" o "esprimen" el metal "robado" de la ropa y vestimenta de los trabajadores. Quizás las chawas referidas varias veces en este texto son como la "leche" de la mina. rechagua y entra después del alferes a desnudar el santo y quitarle los robos que hubiesen escapado la primera requisa". ${ }^{\circ}$

La idea del "robo" de metales resuena directamente con las "estafas" objetadas en 1835 por Pedro Malpartida, respaldado por Pedro Laureano Quesada, las que supuestamente justificaban la rebaja del salario mediante la alza de los precios del género. Pero para fines del siglo las oportunidades y el aliciente habían crecido con la afluencia de capitales internacionales y la presencia de las casas extranjeras de rescate en los mismos centros mineros. Frente a la presión del capital sobre sus salarios, los trabajadores se esforzaban a contrapesar los efectos de la proletarización ejerciendo sus derechos de recolección, ahora ampliados en una situación de boya minera, para después vender el producto metálico a los sucursales locales de las casas internacionales de rescate.

El conflicto entre dos conceptos de legalidad, uno que denunciaba como "hurto" lo que el otro consideraba "derecho de recolección", se mantenía a lo largo del siglo XX y sigue hasta hoy. Tiene en sus raíces la tensión entre los dos polos de una antigua reciprocidad distributiva entre los contribuyentes de trabajo y los que ponen el objeto y medios de trabajar (cf. el mink'a, o chuqhu festivos en los Andes), aunque hemos visto que tanto el caccha como el fomentador pudo ser el propietario de la mina. En el contexto minero, se trata de una versión del antiguo y persistente conflicto entre la propiedad privada como base de la acumulación originaria, y los derechos de cultivo y recolección de la comunidad (Thompson 2000 [1991]). La arqueología conceptual llevada a cabo en este artículo nos muestra, nuevamente, la base histórica para la idea de una asociación legitima entre fomentador y caccha en trabajos de pequeña escala, un acuerdo pactado que es negado, en cuanto avanza cada ciclo minero, por el emergente y creciente antagonismo entre el capital y el trabajo.

Agradecimientos Al apoyo del Instituto de Estudios Peruanos (Lima) y al Archivo Nacional de Bolivia (Sucre) entre 1980 y 1984, junto con la orientación de Gunnar Mendoza y la colaboración de Antonio Rojas Rosales. También mis agradecimientos a Concepción Gavira por sus comentarios.

${ }^{76}$ El Tiempo, Potosí, Año 1, nº 39. 10.x.1885. 


\section{* Referencias citadas}

\section{Archivos (con abreviaciones)}

Archivo Histórico de Potosí AHP.

Archivo Nacional de Bolivia ANB.

Escrituras Notariales EN.

Ministerio de Hacienda MH.

Potosi Prefecturas Recibidas PPR.

Prefectura Departamental (Correspondencia) PD.

Prefectura Departamental (Expedientes) PDE.

Tribunal General de Minería. TGM.

\section{Folletos}

- "Diccionario de Minería", en Prontuario de los juicios ... Chuquisaca 1830 [Biblioteca Nacional de Bolivia, Moreno 531].

- Código Mineral Santa Cruz. 1835. Imprenta Chuquisaqueña administrada por Manuel Venancio de Castillo. Sucre [Biblioteca Nacional de Bolivia, Moreno 422 III].

- Junta General de Azogueros. 1835. Piden la suspensión del Código Mineral. [Biblioteca Nacional de Bolivia, Bb 330].

- Quesada, Pedro Laureano. Observaciones al Código de Minería, publicado en 2 de abril de 1835 ... [Biblioteca Nacional de Bolivia, Moreno $422 . I V]$.

- Reglamento General de los Trabajos Mineralógicos y Metalúrgicos de la Sociedad Ancona. Potosí: Imprenta Pública de Castillo. 1855 [Biblioteca Nacional de Bolivia].

\section{Publicaciones}

AILLÓN SORIA, E. 2009. Vida, pasión y negocios: el propietario de la Viña San Pedro Mártir, Indalecio González de Socasa (1755-1820). Potosíy Cinti a fines de la Colonia y en la Guerra de la Independencia. Archivo y Biblioteca Nacionales de Bolivia, Sucre.

BARGALLÓ, M. 1969. La amalgamación de los minerales de plata en Hispanoamérica colonial. Fondo de Cultura Económica, México.

CONTI, V. E. 2003. Circuitos mercantiles, medios de pago y estrategias en Salta y Jujuy (1820-1852). En La desintegración de la economía colonial. Comercio y moneda en el interior del espacio colonial (1800-1860), A. Irigoin y R. Schmit (comp.), pp. 113-133. Biblos, Buenos Aires,

CONTI, V. 2001. Salta entre el Atlántico y el Pacífico. Vinculaciones mercantiles y producciones en el siglo XIX. En Cruzando la Cordillera... La frontera argentino-chilena como espacio social, S. Bandieri (coord.), pp. 233 - 261. Universidad Nacional del Comahue, Neuquén.

CONTI, V. 2008. Una empresa mercantil familiar en el espacio económico surandino. Tezanos Pinto y Cía. 1794-1854. En Las escalas de la historia comparada, Tomo 2, Empresas y empresarios. La cuestión regional, S. Bandieri, G. Blanco, M. Blanco (comp.), pp. 29-55. Miño y Dávila Editores, Buenos Aires.

CRESPO RODAS, A. et al. 1984. Siporo, Historia de una Hacienda. Editorial Don Bosco, La Paz.

GAVIRA, C. 2005. Historia de una crisis: La minería en Oruro a fines del período colonial. IFEA/ IEB/ ASDI, La Paz.

GAVIRA, C. 2013. Minería en Chayanta: la sublevación indígena y el auge minero, 1775-1792. Plural editores, La Paz.

LECHTMAN, H. 1976. A Metallurgical Site Survey in the Peruvian Andes. Journal of Field Archaeology 3: 1-42.

LEMA, A. M. et al. (comps). 1994. Bosquejo del estado en que se halla la riqueza nacional de Bolivia ... Año de 1830. Plural Editores / Universidad Mayor de San Andrés, La Paz

MITRE, A. 1981. Los patriarcas de la plata. Instituto de Estudios Peruanos, Lima.

MITRE, A. 1986. El monedero de los Andes. HISBOL, La Paz.

PARKERSON, P. 1976. La política minera de Andrés Santa Cruz (1829-1835). Historia y Cultura 2: pp. 151-170.

PEELE, R. 1893. A Primitive Smelting Furnace. The School of Mines Quarterly 15: 8-10.

PLATT, T. 1986. Estado tributario y librecambismo. HISBOL, La Paz.

PLATT, T. 1992. Divine protection and liberal damnation: exchanging metaphors in 19 th century Potosí. En Contesting markets: Analyses of ideology, discourse and practice, R. Dilley (ed.), pp. 131-158. Edinburgh University Press, Edinburgh.

PLATT, T. 1996. Producción, tecnología y trabajo en la Rivera de Potosí. En El Siglo XIX. Bolivia y América Latina, R. Barragán, D. Cajías, S. Qayum (comps.), pp. 395-435. Institut Français d'Études Andines - Embajada de Francia - Coordinadora de historia, La Paz. 
PLATT, T. 1998. Historias unidas, memorias escindidas: las empresas mineras de los hermanos Ortiz y la formación de las élites nacionales. Universidad Simón Bolivar, Sucre.

PLATT, T. 1998-99. La alquimia de la modernidad. Los fondos de cobre de Alonso Barba y la independencia de la metalurgia boliviana (1780-1880). Población y Sociedad 6/7: 69-142.

PLATT, T. 2012. Container transport: from skin bags to iron flasks. Changing technologies of quicksilver packaging between Almadén and America, 1788-1848. Past \& Present 214: 205-253.

RODRIGUEZ OSTRIA, G. 1989. Kajchas, Trapicheros y Ladrones de Mineral en Bolivia (1824-1900). Revista de Historia 4(8): 125139.

RODRIGUEZ OSTRIA, G. 1991. El socavón y el sindicato: ensayos históricos sobre los trabajadores mineros, siglos XIX-XX. Ildis, La Paz.
SCHELCHKOV, A. 2007. La utopía social conservadora en Bolivia: el gobierno de Manuel Isidoro Belzu, 1848-1855. Academia de Ciencias de Rusia, Centro de Estudios Latinoamericanos, Moscú

TANDETER, E. 1992. Coacción y mercado. La minería de la plata en el Potosí colonial, 1692-1826. Editorial Sudamericana, Buenos Aires.

TELLES, I. A. 1831. Principios Físico-Químico-Prácticos en memorias, para estraer la plata que contengan los minerales. Imprenta Boliviana, Sucre.

THOMPSON, E. P. 2000 [1991]. Costumbres en común. Crítica, Barcelona.

VAN BUREN, M. y B.H. MILLS. 2005. Huayrachinas and Tocochimbos: Traditional Smelting Technology of the Southern Andes. Latin American Antiquity, 16(1): 3-25. 